\title{
Dr. Fuad Umay ve Çocuk Esirgeme Kurumu faaliyetleri
}

\section{Burcu DENIZ ${ }^{1}$}

Sezai ÖZTAŞ²

\begin{abstract}
APA: Deniz, B.; Öztaş, S. (2020). Dr. Fuad Umay ve Çocuk Esirgeme Kurumu faaliyetleri. RumeliDE Dil ve Edebiyat Araştırmaları Dergisi, (19), 558-580. DOI: 10.29000/rumelide.752512.
\end{abstract}

\section{$\ddot{O} \mathbf{z}$}

Dr. Fuad Umay gerek doktor kimliğiyle gerekse milletvekili kimliğiyle Kırklareli’nin yetiştirdiği önemli devlet adamlarından birisidir. Osmanlı'nın son dönemlerine tanıklık etmiş ve yeni kurulan Türkiye Cumhuriyeti’nin en zor günlerinde milletvekilliği yapmıştır. O, çocukların koruyucusu olarak tanınmaktadır. Bu nedenle Mustafa Kemal Atatürk’ün ona verdiği Umay soyadı tam olarak onunla anlam bulmuştur. Dr. Fuad Umay, cemiyet adamı kimliğiyle ön plana çıkmaktadır. Bu cemiyetçi kimliğinden en önemlisi kimsesiz çocukları himaye etmek amacıyla kurduğu Himaye-i Etfâl Cemiyetidir. İşte bu cemiyetin izleri günümüze kadar gelmiştir. Ayrıca Dr. Fuad Umay, çocuklar konusunda Türkiye Büyük Millet Meclisine sunduğu çeşitli kanun teklifleriyle çocuklara sahip çıkarak sağlıklı bir nesil yaratmaya çalışmıştır. Bu çalışmada, Dr. Fuad Umay’ın hayatı, onun kurduğu Himaye-i Etfâl Cemiyetinin Çocuk Esirgeme Kurumuna dönüşüm süreci ve Dr. Fuad Umay’ın Çocuk Esirgeme Kurumu Faaliyetleri aktarılmaya çalışılmıştır.

Anahtar kelimeler: Dr. Fuad Umay, Himaye-i Etfâl Cemiyeti, Çocuk Esirgeme Kurumu

\section{Dr. Fuad Umay and activities regarding Child Protection Agency}

\begin{abstract}
Dr. Fuad Umay is one of the the important statesmen raised by Kurklareli with both his identity has a doctor and as a member of parliement. Having witnessed the late Ottoman period, he served as a member of parliement in the most difficult days of a newly established Parliament of the Republic of Turkey. He has been known as the protector of children. For this reason, the "Umay" surname given to him by Mustafa Kemal Ataturk found meaning exactly with him. Dr. Fuad Umay, stands out with his identity of community man. Himaye-i Etfal Community, which he founded to protect orphans is the most striking reflection of this community identity. Even today, is it possible to see the traces of this community. In addition, Dr. Fuad Umay tried to create a healthy with his various legislative proposals presented to the Grand National Assembly of Turkey aiming at protecting children's rights. In this study, we tried to explain the life of Dr. Fuad Umay the transformation process of Himaye-i Etfal Community, which he founded to the Child Protection Agency, and Dr. Fuad Umay's activities regarding the Child Protection Agency.
\end{abstract}

Keywords: Dr. Fuad Umay, Himaye-i Etfal Community, Child Protection Agency

\section{Giriş}

YL Öğrencisi, Kırklareli Üniversitesi, Sosyal Bilimler Enstitüsü, Tarih ABD (Kırklareli, Türkiye), brcum100691@hotmail.com, oooo-0002-0045-6660 [Makale kaytt tarihi: 15.05.2020-kabul tarihi: 20.06.2020; DOI: 10.29000/rumelide.752512]

2 Doç. Dr., Tekirdağ Namık Kemal Üniversitesi, Fen Edebiyat Fakültesi, Tarih Bölümü (Tekirdağ, Türkiye), sezaioztaş@hotmail.com, 00oo-0002-1742-4200. 
Türkiye Cumhuriyeti Devleti, bitmeyen bölgesel savaşların ve insanlık tarihinde ciddi yıkıcı etkileri olan 1. Dünya Savaşı'nın tüm Avrupa ve Osmanlı Devleti’ni derinden etkilediği bir dönemde yaşamıştır. Milleti ve ülkesi için doğru pozisyon alarak çeşitli zorluklara direnmiş ve hayatlarını ortaya koymuş şahsiyetlerin düşünce tarzlarının ve hayatlarının aradan yaklaşık bir asır da geçmiş olsa araştırılması ve gelecek kuşaklara aktarılması Türkiye'de Cumhuriyet Tarihi alanının gelişimi bakımından kritik öneme haiz bir iştir.

Bu önemli şahsiyetler Türk Tarihi'nde ve Cumhuriyet Dönemi’nde yaptıklarıyla Türk Milletine ve Cumhuriyeti’ne kalıcı eserler bırakmışlardır. Çöken bir imparatorluktan yeni ve modern bir devlete geçiş sürecinde, yeni devletin inşasında sosyal politika gibi kritik bir alanda öncü rolü üstlenmiş, modern anlamda sivil toplum faaliyetlerinin kurumsallaşmasında ilklerden olmuş, idari engellerin kaldırılması ve toplumsal sorunların çözümünde çığır açmış şahsiyetlerden birisi Dr. Mehmet Fuad Umay'dır. Çok önemli bir şahsiyet olmasına rağmen savaş alanlarında olmasa da, politika ve idari sahada Mustafa Kemal Atatürk'ün her zaman yanında ve yakınında olan Dr. Fuad Umay'ın bilinirliğinin Türk kamuoyunda yeterli düzeyde olduğunu söylemek güçtür.

Bu çalışmada, tıp doktoru olan ve sosyal politika alanında topluma çok önemli katkılar sağlamış Dr. Fuad Umay’ın hayatı ve eserleri, imkânlar ölçüsünde, TBMM tutanakları, kendi yazmış olduğu eserler, doğrudan ve dolaylı olarak Dr. Fuad Umay'ı anlatan çalışmalar, dönemin gazete haberleri, başkalarına yapmış olduğu anlatımlar vb. ulaşılabilen eserler üzerinden incelenmiştir. Dr. Fuad Umay’ın milletvekili, doktor ve cemiyetçi kimliğiyle öne çıkması onun topluma sağladığı katkılarının ne derece geniş bir yelpazede yer aldığını doğrulamaktadır. Bu açıdan bakıldığında Dr. Fuad Umay, Türk halkına sunduğu bu hizmetlerin sonucu olarak günümüze kadar varlığını anımsatacak çalışmalar bırakmıştır.

Dr. Fuad Umay'ın hayatı anlatılırken, yukarıda çizdiğimiz çerçevede bir yaklaşım belirlenmiş, içinde bulunduğu toplumsal ve siyasi şartlara da değinilme ihtiyacı hissedilmiştir. 3

\section{Dr. Fuad Umay'in hayatı}

\subsection{Ailesi, eğitim hayatı ve doktorluk yaptığı dönem}

Asıl adı Mehmed Fuad Umay'dır. 24 Şubat 1885 yllında Kırklareli'de4 doğmuştur. 1 Temmuz 1963 yılında İstanbul'da vefat etmiştir. Annesi Seniyye Hanımefendi, babası ise Mehmet Nuri Bey'dir. Dr. Fuad Umay 1961 yılında daktilo ile kaleme aldığı "Hayatım" adlı otobiyografisinde babasının Oğuz Türklerinin Akarap oymağının Mısırlığulları ailesinden geldiğini belirtmiştir. 1914 yılında Kırklareli Belediye Tabipliği döneminde Medhiye Hanım ile evlenerek bu evliliğinden Mübeşşer, Esin, Turhan ve Tunç isimli 2 kız ve 2 erkek evlat sahibi olmuştur (Akın, 2000, ss. 1-3).

Eğitim hayatıyla ilgili olarak Kırklareli’de doğup büyüdüğünden dolayı Mekteb-i İptidai (ilkokul) ve Rüşdiye (ortaokul) eğitimini Kırklareli’de tamamlamıştır. İdadi eğitimine yani lise düzeyinde eğitimine devam etmek üzere Edirne'ye giderek Edirne İdadisi (Lisesi)'nden mezun olmuştur (Akın, 2000, s. 1). Edirne o dönem 600 binden fazla nüfusuyla Osmanlı'nın en önemli kenti konumundadır (Genelkurmay Başkanlığı, 2005, s. 663). Dr. Fuad Umay'ın çocukluk ve gençlik yılları, Osmanlı'nın Rumeli'de sürekli toprak kaybı yaşadı̆̆ı döneme denk gelmiştir. İmparatorluğun içinde bulunduğu durum ve savaşlar

\footnotetext{
3 Örneğin, Kırklareli doğumlu Dr. Fuad Umay’ın ilk milletvekili seçilmesini neden Kırklareli değil de, Bolu olduğunu açıklamak için Milli Mücadele ylllarında millet ve memleket için Bolu'da vermiş olduğu hizmetler ve yürütmüş olduğu faaliyetlerin genel bir çerçevesi ortaya konularak değerlendirilmiştir. 
sonucunda ekonomik, sosyal ve siyasal alanda yaşanan çöküşün gün geçtikçe büyümesi Dr. Fuad Umay'ın hayata bakışı ve mesleki tercihinde önemli rol oynamıştır. Üniversite eğitimi için İstanbul'a gelmiş ve alan olarak Tıbbiyeyi tercih etmiştir. İlk görev yeri, bugün Bulgaristan sınırları içinde yer alan Tırnova kasabasıdır. Burada Tırnova Kazası Belediye Tabibi olarak göreve başlamıştır. Öğrencilik yıllarında İttihatçı fikirlerden etkilenmiş ve bu fikirleriyle ilerleyen yıllarda dikkatleri üzerine toplamıştır (Akın, 2000, s. 1). Cahit Kayra da, Dr. Fuad Umay'ı 1908 kuşağından olan Kemalist bir devrimci olarak tanımlamıştır (Kayra, 2014, s. 7).

Genç Dr. Fuad Umay'ın ilk görev yeri Tirnova olup, ilk mesleki mücadelesi ise Frengi Hastalı̆̆ ile olmuştur. Bu dönemde Frengi halk arasında artış göstermiştir. ${ }^{5}$ Hastalığın Osmanlı topraklarına ne zaman geldiğine ilişkin en kuvvetli iddia ise 1810 yllından itibaren etkisini göstererek 1854 Kırım Savaşı ile yaygınlaşmış olmasıdır (Martal, 2007, s. 117). Dr. Fuad Umay, hastalığın yaygınlaşmasında evlenme vakalarının kontrolsüz bir şekilde gerçekleştirilmesinin önemli rol oynadığını tespit etmiştir. Genç çiftlerin nikâhları papazlar tarafından ve belirli bir ücret karşılığı kıyıldığından dolayı papazlar bu durumu kendi çıkar alanlarına müdahale olarak algılayarak Dr. Fuad Umay'ın toplum sağlığına yönelik çabalarını engellemeye çalışmıştır. Bu durum karşısında Dr. Fuad Umay, sağlık muayenesi olmaksızın genç kızların evlenmelerinin mümkün olamayacağına dair aldığı bir kararı, kasaba ahalisine duyurmuş ve böylece bizzat halkı bilgilendirme çabasına girişmiştir. Belirli bir süre sonunda Dr. Fuad Umay önce yerel halkı ardından papazları ikna etmeyi başararak halkın güvenini ve sevgisini kazanmıştır (Akın, 2000, s. 28).

Dr. Fuad Umay'ın, Frengi hastalığı ile mücadelesi Tırnova'dan sonraki görev yeri olan Kırklareli'de de devam etmiştir. Hastalığın kontrolsüz bir şekilde yayılmasını önlemek maksadıyla hazırlamış olduğu teknik raporu o dönemin Shhhat Müdürlüğüne ${ }^{6}$ sunmuştur. Hastalı̆̆ı başkasına bulaştıranlara cezai yaptırımlar öngören bu rapor 14 Ağustos 1920 tarihinde Bolu Mebusu olarak görev yaptığı 1. TBMM'de sunacağı ikinci kanun teklifinin nüvesini oluşturmuştur (Akın, 2000, s. 29). Bugün frengi ve belsoğukluğu gibi hastalıkların halk sağlığının tehdit eden hastalıklar arasında olmaması ve Türkiye Cumhuriyeti'nde kıyılan nikâhlardan evvel çiftlerin sağlık muayenesinden geçmesi Dr. Fuad Umay'ın Tırnova'da yaşamış olduğu tecrübe ve çabalarının bir sonucu olarak karşımıza çıkmaktadır. Dr. Fuad Umay, Tırnova'daki görevine devam ederken Balkan Savaşları'nın başlamasıyla birlikte bölgenin askeri hastanesinde görev almıştır. Savaşın bitmesinin ardından 28 Ağustos 1913 tarihinde Kurklareli Belediye Tabipliğine tayin olmuştur (Akın, 2000, s. 2). Dr. Fuad Umay, Kırkkilise Belediye Tabipliği görevi sürecinde halk sağlığını ilgilendiren hususlarda özellikle savaşın yıkıcı etkilerine maruz kalmış çocuklara ilişkin sosyal politika alanlarında kamu hizmeti vermenin sorumluluğunu yerine getirmeye çalışmıştır.

\subsection{Bolu'da geçirdiği yıllar (Bolu'da Milli Mücadele'ye katkıları, Heyet-i Nasiha görevi ve milletvekilliği dönemi)}

Dr. Fuad Umay'ın Kurklareli'deki faaliyetleri sadece hekimlik ve Himaye-i Etfâl Cemiyeti üzerinden çocukların himayesi ile sınırlı kalmamıştır. Dr. Fuad Umay Milli Mücadele döneminde de aktif rol almıştır. İttihad ve Terakki Fırkasına intisap ederek fırkanın faaliyetlerine katılım sağlamış ayrıca bu fırkanın destekçi cemiyetlerinden olan Müdafaa-i Milliye Cemiyetinin Kırklareli şubesinin kuruluşunda yer almıştır (Dursunkaya, 1948, s. 148).

\footnotetext{
$5 \quad$ Frengi, cinsel yolla bulaşan, kalıtsal olarak yeni doğan bebeklere geçebilen, halk sağlığını tehdit eden zührevi bir hastalıktır. (Bulut, 2009, 110).

Shhhat Müdürlüğü: İl Sağlık Müdürlüğü, (TDK, 2009).
} 
Dr. Fuad Umay'ın Kırklareli'deki faaliyetlerinin ardından Bolu'da Müdafaa-i Hukuk Cemiyetinin nüvesini oluşturan ilk girişim, kaymakam vekili Mithat Kemal Bey tarafından Redd-i İlhak Cemiyeti adıyla yapılmıştır (Sarıkoyuncu, 1992, s. 113). Bu cemiyetin ismi Dr. Fuad Umay'ın başkan seçilmesiyle 15 Ekim 1919 tarihinde Bolu Müdafaa-i Hukuk Cemiyeti olmuştur. Dr. Fuad Umay Milli Mücadele döneminde Mustafa Kemal Paşa'nın sadık destekçilerinden olmuştur. Sivas Kongresi sonrasında İstanbul Hükümeti’nin Anadolu illeri üzerindeki etkisinin kırılmasında jeostratejik konumda bulunan Bolu'nun, Milli Mücadele tarafında yer almasında önemli katkılar sağlamıştır (Kılıç, 2011, s. 31). Görüldüğü üzere sadece Bolu merkezli örgütlenmelerde değil, ilçe örgütlenmeleri ile çevre illerdeki örgütlenmelerde de Dr. Fuad Umay öncü rol oynamıştır (Evcin, 2011, s. 455). Sivas Kongresi’nde alınan karar gereği Anadolu illerinin İstanbul hükümeti ile ilişkilerinin kesilmesinde Mustafa Kemal Paşa'dan gelen talimatın yerine getirilmesinde Bolu vilayet binasında tertip edilen toplantıda lehte ilk söz alan kişi Dr. Fuad Umay olmuştur (Akın, 2000, s. 6). Dr. Fuad Umay, İstanbul Hükümeti'nin artık hükmünü yitirdiği ve millet menfaati yönünde karar alınmasını ifade eden bir konuşma yapmıştır (Umay, 1950, ss. 4-5). İtilaf Devletleri’nin Osmanlı Devleti üzerindeki egemenlik paylaşımını Dr. Fuad Umay'ın imzasıyla çekilen telgrafla protesto eden, 116 Anadolu yerleşim biriminden birisi yine Bolu olmuştur (Şimşir, 1992, ss. 346-355). Bolu'nun Milli Mücadele döneminde düşman kuvvetlerine karşı gösterdiği bu tavır diğer illere de örnek olmuştur.

Bolu'da 1 Nisan 1920’de, TBMM’nin 1. döneminde Bolu’yu temsil etmek üzere seçilen temsilciler, Bolu Müdafaa-i Hukuk Cemiyetinin önerdiği adaylar içinden seçilmiştir. Adaylar arasında, 9 Nisan 1920'de Bolu'dan ayrılan heyette olan ve TBMM'nin 1. döneminde Bolu Mebusu olarak görev yapacak Cemiyet Başkanı Dr. Fuad Umay, Nuri Efendi, İlyaszade Şükrü Bey ve Hacı Abdul Vahap Bey bulunmaktadır (Tütüncü, 1996, s. 10). Dr. Fuad Umay, Bolu Mebusu olarak seçilince 1 Nisan 1920 tarihi itibarıyla Bolu Müdafaa-i Hukuk Cemiyetindeki görevi son bulmuş, 11 kişilik yeni bir yönetim kurulu oluşturulmuştur (Yllmaz, 1991, s. 106).

Dr. Fuad Umay'ın Bolu'da geçirdiği ylllarda Heyet-i Nasiha görevi de bulunmaktadır. Heyet-i Nasihanın üyeleri arasında Bolu mebusları Dr. Fuad Umay, İlyaszade Şükrü Bey, Hüsrev Bey ve Osman Nuri Bey yer almıştır (Çağlar, 1990, ss. 87-88). Heyet-i Nasiha üyeleri, isyancılardan Çerkez Nuri tarafından Düzce'ye götürülerek tutuklanmış ve infaz edilmeleri gerektiğine dair tartışmalar başlamıştır. Ancak Sefer Bey aracılığıyla Mustafa Kemal Paşa tarafından uzlaşma kararı alınmış olsa da Çerkez Ethem uzlaşmayı dikkate almamıştır. Kasabanın işgalinden sonra Sefer Bey'in de aralarında bulunduğu 20'den fazla kişiyi hızlı bir şekilde idam ettirmesiyle birlikte isyan son bulmuştur (Akın, 2000, ss. 17-21).

Mustafa Kemal Paşa'nın 19 Mart 1920 tarihli kararına istinaden 1 Nisan 1920 tarihinde yapılan seçimler neticesinde Bolu milletvekilleri olarak Dr. Fuad Umay, Hacı Abdul Vahab, İlyaszade Şükrü ve Hacı Abdullah Nuri Bey seçilmiştir (Konukçu, 1978, s. 30).

Dr. Fuad Umay'ın TBMM 1. dönemindeki çalışmaları Mustafa Kemal Paşa tarafından takdirle karşılanmış, kendisi Himaye-i Etfâl Cemiyeti için maddi yardım toplamak maksadıyla gönderildiği ABD seyahatinde iken TBMM Reisi Mustafa Kemal Paşa tarafından Kırklareli'den milletvekili adayı olarak gösterilmiştir. Böylece Anadolu ve Rumeli Müdafaa-i Hukuk Grubu'nun Kırklareli adayı olduğu seçimlerde, TBMM'ye Kurklareli vekili olarak girmiştir. Dr. Fuad Umay 1923-1950 ylları arasında TBMM'nin 1-8. (1, 2, 3, 4, 5, 6, 7 ve 8.) dönemlerinde kesintisiz Kurklareli Milletvekili olarak görev yapmıştır. 
Dr. Fuad Umay'ın TBMM 2. Dönemde ilk faaliyeti “(Kırkkilise) isminin (Kırklareli)'ne Tahvili Hakkında" vermiş olduğu takrirdir. Bu teklifine ilişkin Umay "Kırkkilise'nin fethinde büyük yararlılıkları görülen ve kırklar semtinde meftun bulunan kahramanların isimlerine izafeten Kırkkilise'nin Kırklareli ünvanına tebdili hakkındaki teklifim meclisce kabul edilmiştir.” (Umay, 1950, s. 12) diyerek başardığı işler arasında bu hususu da zikretmiştir. Dursunkaya, Kırkkilise yerine Kırklareli isminin verilmesine ilişkin memnuniyetini "Nihayet, yıllardan beri bize aykırı gelen (Kırkkilise) adı milletvekilimiz Dr. Fuat Umay’ın bir teklif takriri üzerine Büyük Millet Meclisince kabul edilen Kanunla (Kırklareli) ye değiştirilmiştir.” şeklinde ifade etmiştir (Dursunkaya, 1948, s. 148).

\subsection{Amerika seyahati}

Dr. Fuad Umay tarafından Himaye-i Etfal Cemiyeti aracılığıyla Amerika'ya seyahat düzenlenmiştir. Öncelikle seyahatin Amerika'ya yapılmasının nedenlerinden bahsetmemiz gerekmektedir. Bunun üç temel nedeni bulunmaktadır. Amerika 1. Dünya Savaşı'ndan sonra ekonomik gücünü elinde tutan ülkeler arasında yer almıştır. Bu sebeple temel neden ekonomik olarak güçlü bir ülke olmasıdır. Diğer bir nedeni Amerika'da çok fazla sayıda Türk ve Müslüman nüfusun bulunmasıdır. Ayrıca Amerika sosyal konular ve kurumlar açısından gelişmiş bir ülke konumunda idi (Acar, 2011, s. 14). Yani Amerika'da Türkiye'ye örnek teşkil edecek sosyal kurumlar bulunduğundan dolayı Amerika seyahati uygun görülmüştür. Dr. Fuad Umay, New York ile ilgili anısında şu notları almıştır:

...New York’u seyrettim. Binaların büyüklüğü, elektrik ile yapılan reklamların biçimleri ve türleri insanı şaşırtıyordu. Bunları görünce; uzun zamandan beri felaketlerin en büyüklerine maruz bırakılmış zavallı memleketimin yoksulluğu gözümün önünde canlandı, üzüldüm... (Umay, 2014, s. 7).

Amerika'nın sosyo-ekonomik durumu hakkında bu şekilde bilgi edindikten sonra bir de Türkiye'nin sosyo-ekonomik durumuna bakmak gerekmektedir. Amerika bu dönemde dünyanın önde gelen ülkeleri arasında yer alırken Türkiye sanayi anlamında fazla gelişmemiş, nüfusunun büyük çoğunluğu tarım ve hayvancılıkla geçinen bir ülkedir. İnsanların ortalama ömrü Batı ülkelerinde elli yaşın üzerinde iken Türkiye’de cumhuriyetin ilan edildiği ilk yıllarda otuz yaşın üzerine çımamıştır. Savaş yıllarında verilen 5-7 milyon insan kaybının yanı sıra koşulların elverişsiz olması, açlık, bilgisizlik, tıbbi araç gereçlerin noksan olması ve hasta olanaklarının yetersizliği ölüm oranlarını arttırıcı faktörler arasında yer almıştır (Toprak, 2017, s. 22).

Dr. Fuad Umay, sanayileşme adına bazı faaliyetlerde bulunmuştur. Bu sebeple Amerika'da kurulan dokuma fabrikalarını ve Ford fabrikasını ziyaret etmiştir (Umay, 2014, s. 11). Tarım ve hayvancılıkla geçinen Türkiye'de, bu ziyaretler sonucunda sanayileşme adına yapılan çalışmalara zemin hazırlanmıştır. Böylece Amerika'da ki bu kurumlar Türkiye'de kurulacak olan kurumlara örnek teşkil etmiştir.

Dr. Fuad Umay, Amerika ile Türkiye arasında oluşturduğu teşkilatlanmayı cemiyetler aracılığıyla yapmıştır. Cemiyetler ile sağlanan bu teşkilatlanmaya Sabiha Sertel öncülük etmiştir. Dr. Fuad Umay'ın Amerika seyahati sırasında Sabiha Sertel yanında bulunmuş ve ona danışmanlık etmiştir. Ayrıca Amerika'daki Türklerle de sık sık görüşmeler yaparak, onları Hilal-i Ahmer ve Teavün gibi cemiyetler aracılığıyla teşkilatlandırmak istemiştir.

Cemiyete maddi kaynak temin etmek amaciyla yapılan bu gezide önemli derecede maddi kaynak toplanmıştır. O dönemde her iki cemiyetin de yaptığı toplantının sonucunda 100.000 dolar civarında 
bir para toplanmıştır (Sertel, 2015, s. 59). Buradan elde edilen paralar Himaye-i Etfâl Cemiyetinin gelir getiren kaynaklarının temelini oluşturmuştur. Dr. Fuad Umay, başlattığı bağış kampanyalarının yanı sıra Türkiye ile ilgili propagandalar yaparak eğitimci gözüyle Amerika'nın eğitim sistemini incelemiştir. Böylece çocuk yetiştirme sisteminin köklerine kadar inerek çocuk olgusunu aile yapısından incelemeye başlamıştır. Ayrıca Dr. Fuad Umay, dönemin en bilinen eğitimcilerinden Prof. John Dewey ile bu konuda önemli görüşmeler yapmıştır (Umay, 2014, ss. 10-11).

1923 yılında Dr. Fuad Umay'ın Amerika seyahati sonucunda Amerika'da yaşayan Türkler tarafından kuruma toplam 152.000 lira bağış yapılmıştır. Kurumun oluşturduğu tesislerin çoğunun inşa edilmesi bu bağışların katkısı sayesinde mümkün olmuştur. TBMM bu bağışlar aracılığıyla Çocuk Esirgeme Kurumu'na 5000 metrekarelik arsa temin etmiş ve kurum tesislerin çoğunu bu arsaların üzerine inşa etmiştir (Bartu, 1946).

\section{Osmanlı Devleti’nde çocuğun himayesi}

\subsection{Osmanlı'dan Cumhuriyet'e çocuk}

Öncelikle, Osmanlı döneminde çocuk ve çocuk algısından kısaca bahsedecek olursak, çocuk ve çocukluk kavramlarının tanımlarından bahsetmek yerinde olacaktır. Bu kavramlar günümüze kadar çok kez tanımlanmıştır. Çocuk "küçük yaştaki oğlan veya kız" ya da "bebeklik ile ergenlik arasındaki gelişme döneminde bulunan oğlan veya kız, uşak” (TDK, 2009) olarak ifade edilmiştir. Çocuk kavramını Çeker (2015, s. 13) ise "Yaş küçüklüğünden dolayı mükellef olmayan insan" olarak tanımlamıştır. Ayrıca genel anlamda çocuk kavramı "insan yavrusudur" denilerek özetlenmiştir (Sarıkaya, 2011, s. 1). Çocukluk ise "doğum ile olgunluk arasındaki dönem" (Okay, 1998, s. 24) olarak tanımlanmaktadır. Başka bir deyişle çocukluk, çocuğun doğumundan itibaren başlayıp olgunlaşana kadar geçen zamana ait değişimleri ifade etmektedir.

Osmanlı Devleti’nde çocuk konusunda önemli olan diğer bir konu sağlık konusu olmuştur. Osmanlı'da çocuk sağlığı ile ilgili bilgiler durumun pek iç açıcı olmadığını göstermiştir. Çünkü bahsedilen dönemlerde bebek ve çocuk ölümleri küçümsenmeyecek kadar önemli bir boyuttadır. 19. yüzyılda çocuk sağlı̆̆ı gibi önemli bir konunun öneminin farkına varılarak, çocukların sağlığının korunmasına çalışılmıştır. Böylece çocuk ilaçları, çocuk aşıları, çocuk doktorları ve çocuk hastaneleri ortaya çıkmaya başlamıştır. Bazı dergilerde ve gazetelerde de çocuk sağlığı ile ilgili halkı bilgilendirme amaçlı yazılara yer verilerek halkın bilinçlendirilmesi böylece çocuk ölümlerinin önüne geçilmesi amaç edinilmiştir (Okay, 1998, s. 72).

Osmanlı Devleti'ndeki sosyal hizmet kurumları, toplumun her kesimindeki bireylere yönelik kolaylaştırıcı faaliyetler sürdürmüştür. Bununla birlikte en çok göze çarpan hizmetlerden biri olarak, korunmaya muhtaç çocuklar için kurulan sosyal hizmet kurumları karşımıza çıkmaktadır. Korunmaya muhtaç çocuk ne demektir? Öncelikle bu sorunun cevabını vermemiz gerekmektedir. 1949'da TBMM tarafindan kabul edilen 5387 sayılı kanunun 1. maddesinde yer alan ve 1957'de 6972 sayılı Korunmaya Muhtaç Çocuklar Hakkında Kanun'unun 1. maddesinde yer alan korunmaya muhtaç çocuk, "Beden, ruh ve ahlak gelişimleri tehlikede olup:
a) Ana ve babasiz,
b) Ana ve babası belli olmayan,
c) Ana ve babası tarafindan terk edilen, 
d) Ana ve babası tarafından ihmal edilip, fuhşa, dilenciliğe, alkollü içkilere ve uyuşturucu maddeleri kullanmaya veya serseriliğe sürüklenmek tehlikesine maruz bulunan çocuklardır.” (Çağlar, 1973, s. 60) şeklinde açıklanmıştır.

Sonuç olarak, korunmaya muhtaç olan çocukların himaye edilerek tüm ihtiyaçlarının karşılanması ve topluma kazandırılması hem devletin hem de toplumun gerçekleştirmesi gereken önemli sorumluluklar arasında yer almıştır (Arslan, 2007, s. 16). Osmanlı Devleti bu sorumlulukları başlangıçta çocuğun ailesine ve yakın akrabalarına bırakmış olsa da ilerleyen zamanda devlet kontrolünde düzenleme çalışmalarına gidilmiştir.

\subsection{Osmanlı Devleti’nde kimsesizler için kurulan sosyal hizmet kurumları}

Her ne kadar Himaye-i Etfâl Cemiyetinin ve dolayısıyla Çocuk Esirgeme Kurumunun oluşum sürecini Cumhuriyet Dönemi olarak nitelendirsek bile bu kuruma dair tohumların Tanzimat'ın ilanıyla birlikte atılmıştır. Çünkü bu dönemde özellikle çocuklara yönelik oluşturulan koruma politikaları ve eğitim kurumları Meşrutiyet döneminde sayı olarak artış göstermiştir. Dolayısıyla çocuklara sunulan hizmet alanları da büyümeye başlamıştır. Milli dayanışma duygusunu geliştirme amacıyla ise devletin eğitim ve sosyal hizmet faaliyetleri ile siyasal nüfuzu kullanılmaya çalışılmıştır (Özbek, 2002, s. 44).

Osmanlı döneminde çocukların himayesi ve eğitimleri ile ilgili olan tüm haklarının korunması ve sürdürülmesi için her türlü önlem alınmıştır. İlk olarak bu görev çocuğun ailesine, yakın akrabalarına ya da sosyal yardım kurumlarına düşmüş olsa da zaman ilerledikçe bu görevi devlet üstlenmiş ve çocuğu himaye etme görevini devlet kontrol etmeye başlamıştır (Araz, 2013, s. 57). Devlet, çocukları himaye etme görevini vakıflar aracılığıyla yaparak yönetimini de onlara bırakmıştır. Vakıfların bireylere hizmet amacı, çocukların korunup eğitilmesi ve çeşitli ihtiyaçlarının karşlanması sonucunda toplum için yararlı bireyler yetiştirmektir (Kapcı, 2016, s. 18).

Osmanlı'nın son dönemlerine bakıldığında, bu dönemin savaşlarla geçmesi, çözümü hiç de kolay olmayan ve devamında büyük sosyal etkiler yaratacak olan bir çocuk meselesiyle ülkeyi karşı karşıya getirmiştir. Cephelerdeki askerlerden tutun da cephe dışında olup hayatlarını kaybeden sivillere kadar birçok çocuk öksüz ve yetim kalmıştır. Dolayısıyla bunları himaye etme ve eğitme görevini de ağırlıklı olarak devlet üstlenmiştir. Ayrıca bu dönemde açılan dernekler de çocuk koruma faaliyetlerine katkıda bulunmuşlardır. Fakat Osmanlı son döneminde tüm tebaaya açık olan Darülhayr-ı Ali, Darüleytam gibi kurumların kurulması yaşanan kimsesiz çocuk sorununu çözmekte yetersiz kalmıştır (Sarıkaya, 2011, s. 5).

Tanzimat öncesi döneme bakıldığında ise yetim çocuklar genel itibariyle toplumun, camilerin ve vakıfların himayesindedir. Bu dönemde kimsesiz çocukların yetim sicilleri tutulmuş, bunlara vasi tayin edilmiş ve nafakaları sağlanmıştır. Ancak Tanzimat sonrasında uygulamalar daha resmi bir hale gelmiştir. Bu dönemde Emvali Eytam Nezareti ve Emvali Eytam Müdüriyeti kurulmuştur.

Tanzimat döneminde ise öncelikle Rumeli'de olmak üzere, öksüz, yetim kız ve erkek çocukların korunup eğitilip topluma kazandırılması düşüncesi ile Islahhane adıyla okullar açılmıştır (Özkan, 2006, s. 213). Bu okullar Mithat Paşa'nın Rumeli'de valilik yaptığı dönem, önce Niş'de (1860), sonra Sofya'da (1864) ve Rusçuk'ta (1865) açılmıştır (Koçer, 1991, s. 68). Çocukları sokaktan kurtarmak ve himaye etmek amacıyla Mithat Paşa'nın girişimiyle Niş'te başlayan bu yapısallaşma kısa süre içinde ülke geneline yayılarak Osmanlı'daki modern mesleki eğitime yön verecek duruma gelmiştir (Yıldırım, 2013, s. 23). 
Osmanlı Devleti'nin kurduğu sosyal hizmet kurumlarından bir diğeri ise darüleytamlardır. Darüleytamlar, dönemin hükümeti İttihat ve Terakki tarafından 1. Dünya Savaşı sonucunda şehit olanların çocuklarına hizmet vermek amaciyla kurulmuştur. Darüleytam kurumunun temelini Darülhayr-ı Ali oluşturmaktadır. Çünkü maddi imkânsızlıklar nedeniyle Darüleytam gibi büyük çaplı bir kurum oluşturulamayıp onun yerine 1903'te Darülhayr-1 Ali'nin temelleri atılmıştır (Özbek, 1999, s. 11). Darülhayr-ı Ali, aynı zamanda Osmanlı Devleti'nin kimsesiz çocuklara yönelik oluşturduğu büyük çaplı ilk kurumdur. Bu kurum yatılı bir okul olarak karşımıza çıkmaktadır. Kurumunun amacı devletin sorumluluğunda ve kontrolünde olan kimsesiz çocuklara sahip çıkmaktır. Ayrıca kimsesiz çocukların geçimlerini sağlamaları amacıyla meslek sahibi edinmeleri amaçlanmıştır. Kurum 400 çocuğa hizmet vermiştir. Ayrıca kurumun öncelikli amacı Müslüman kız ve erkek olan kimsesiz çocuklara hizmet sunmak olsa da ilerleyen dönemde bu kural değişerek gayrimüslim çocuklara da hizmet sunması amaçlanmıştır. Fakat ilk olarak Müslüman erkek çocukların yararlanabileceği bir kurum olarak açılmıştır. Bu durumun sadece bu aşamada kalmasının nedeni dönemin ekonomik imkânsızlıklar içinde bulunmasıdır (Kapcı, 2016, s. 66). İlerleyen zamanlarda sosyo-ekonomik etkenlerin de etkisiyle kimsesiz çocuklar sorununun büyümesi ve bu sebeple halkın girişimiyle üretilen çözümlerin yetersiz kalması sonucunda devlet tarafından bu duruma çözüm aranmaya başlanmıştır. Böylece Darülhayr-ı Ali var olan ihtiyacı karşılayamaması üzerine 22 Ağustos 1909 tarihinde kapatılmıştır (Çavuşoğlu, 2005, s. 8).

Darüleytamlar şehit çocuklarına ve Müslüman ya da gayrimüslim çocuklara yönelik hizmet vermiştir. Ancak ilerleyen süreçte hazinenin para sıkıntısı çekmesi sebebiyle darüleytamlarda bulunan çocukların sayısı azaltılmıştır. Böylece darüleytamlarda bulunan çocuklardan yakın ya da uzak akrabası olanlar bu akrabalarının yanına yerleştirilmişler bazıları da kuruma başvuran iyi ailelere evlatlık olarak verilmişlerdir. Bu şekilde darüleytamların savaş dönemindeki maddi yükü bir nebze de olsa azaltılmaya çalışılmıştır. Darüleytamların hizmet verdiği çocukların yaş sınırı dönem dönem farklılık gösterse de genellikle 12 yaşına kadar olan çocukların alındı̆̆ı görülmektedir. Fakat nadiren de olsa 20-22 yaşlarında asker kaçağı delikanlıların da alındığı olmuştur (Okur, 1996, s. 37).

Osmanlı Devleti’nde kimsesizler için kurulan sosyal hizmet kurumlarından bir başka bir kurum ise Darülaceze'dir. Darülaceze kurumu devletin dilencilikle olan mücadelesi sırasında kurulmuştur. Darülaceze sadece dilencileri değil sokaklarda, cami ve kilise kapılarında terk edilmiş halde bulunan çocukları da himayesi altına almıştır. Zaman içerisinde bünyesinde çeşitli değişiklikler yapılmış olsa da Türkiye'nin en önemli hayır kurumu haline gelmeyi başarabilmiştir (Koçu, 1974, s. 25).

\section{Dr. Fuad Umay ve Çocuk Esirgeme Kurumu}

\subsection{Himaye-i Etfâl Cemiyetinin ilk kurulduğu yer ve Dr. Fuad Umay'ın cemiyete katkıları}

Himaye-i Etfâl Cemiyetinin kuruluşuna dair birçok farklı bilgi bulunmaktadır. Bu nedenle farklı kaynaklardan edinilen bilgilere göre görüş birliğine varmak zor gibi görünse de, konuyla ilgili incelenen kaynaklar doğrultusunda güçlü olan iki farklı tarih mevcuttur. Kaynakların bir kısmında Osmanlı Dönemi'nde Himaye-i Etfâl Cemiyetinin olduğundan bile bahsedilmemiş Çocuk Esirgeme Kurumunun kuruluş tarihi 1921 olarak verilmiş ve kurumun Ankara'da kurulduğu bilgisi verilmiştir. Diğer bir bölümde yer alan kaynaklarda ise Osmanlı Dönemi'nde Himaye-i Etfâl Cemiyeti gibi bir kurum olduğundan bahsedilmiştir (Acar, 2011, ss. 9-10). Konuyla ilgili kaynaklardan elde edinilen bilgilere göre, Osmanlı Devleti döneminde kurulan Himaye-i Etfâl Cemiyetinin ilk kuruluş yllı 
1908'dir. 1908'de ilk kez Kırklareli'de kurulmuştur. Böylece Kırklareli, Türkiye Çocuk Esirgeme Kurumunun temelinin atıldığı yer olarak tarihe geçmiştir (Bartu, 1946). "Kırklareli bu eserle her vakit övünebilir.” (Dursunkaya, 1948, s. 154). Kurum, Balkan Savaşı'na kadar faaliyetlerini sürdürmüştür. Ancak Balkan Savaşı, Trablusgarp Savaşı ve ardından 1. Dünya Savaşı'nın olumsuz ve kötü şartları sonucunda milyonlarca genç cephelerde kalmış, kimsesiz ve bakımsız Türk evlatlarını himaye etmek üzerine çalışmalarını sürdüren kurumlar ihtiyacı karşılayamaz olmuştur (Bartu, 1946).

İstanbul'da kurulan Himaye-i Etfâl Cemiyeti, Kırklareli'de bulunan cemiyet ile birleşmiştir. Böylece cemiyetin merkezi İstanbul Himaye-i Etfâl Cemiyeti olarak faaliyetlerini buradan yürütmeye başlamıştır (Çavuşoğlu, 2005, s. 4). Bundan sonra Ankara'da yeni bir cemiyet açlıncaya kadar cemiyetin adı İstanbul Himaye-i Etfâl Cemiyeti olmaktan çımış, tek bir çatı altında birleştirildiği için Himaye-i Etfâl Cemiyeti olarak dile getirilmiştir. Cemiyet, ilk faaliyet olarak 1. Dünya Savaşı'nda yetim ve öksüz kalmış çocukları korumak amacıyla 1917 yılının sonlarında İstanbul Firuzağa'da bir çocuk misafirhanesi kurmuştur. İlk olarak 100 kişi kapasite ile açılan misafirhanenin kapasitesi daha sonra arttırılmıştır. Öğretmenler, misafirhanede barınan öğrencilerin eğitiminden sorumlu olmuşlardır. Cemiyet, misafirhaneye öğrenci alımını hayırsever olan ailelere gazeteler vasıtasıyla duyurmuştur (Okay, 1999, s. 32). Himaye-i Etfâl Cemiyeti, kurulduğu ilk ylllarda hizmet verdiği hiçbir çocuğu cins, mezhep ve milliyet olarak ayırt etmemiş ülkede zor durumda kalan her çocuğa hizmet vermiştir. Ancak 1. Dünya Savaşı bittikten sonra imzalanan Mondros Mütarekesi ile birlikte bazı kuruluşlar kendi dinlerinden olan çocukları koruma altına almıştır. Böylece cemiyet yalnızca Müslüman olan çocuklara hizmet vermeye başlamıştır (Okay, 1999, s. 35).

Cemiyetin diğer bir faaliyeti Kalender'de "Ziraat Yurdu" açmasıdır. Ziraat Yurdu, çocukların toprakla uğraşmaları sonucunda topraktan ürün almayı alışkanlık haline getirmek ve hayvancılığa ait bilgiler sunmak amacıyla kurulmuştur (Okay, 1999, s. 34). Ziraat Yurdu mali yardımların kesilmesine uzun süre dayanamaması sebebiyle 1931 yılında kapanmıştır (Sarıkaya, 2012, s. 98).

Kurum sadece çocuk ile ilgilenmeyerek çocuk ile anneyi birlikte ele almıştır. Böylece diğer çalışmasını anne-çocuk sağlığına yönelik olarak yapmıştır. Açtığı dispanserlerle hastaları muayene etmiş, ücretsiz ilaç dağıtımı yapmıştır. Dispanserler ilk olarak Şehzadebaşı, Bakırköy ve Üsküdar'da açılmıştır (Çavuşoğlu, 2005, s. 10).

Himaye-i Etfâl Cemiyetinin amaçları ve kuralları net bir şekilde nizamnamede açılanmıştır. Cemiyetin nizamnamesine göre, cemiyette himaye edilecek olan çocukların belli bir yaş sınırı bulunmaktadır. Bu yaş sınırı 13'tür. Ancak Merkez Heyeti gerekli görürse yüksek yaşta bulunan çocukları da himaye etme hakkına sahiptir. Cemiyetin önemsediği konular arasında çocukların sağllk ve ahlak sorunları da yer almıştır. Cemiyet sağlık konusunda çocukların sağlıklı ortamlarda ve okullarda eğitim görmesini gerekli görmüştür. Böylece cemiyet bazı yerlere hastane ve sanatoryum inşasını başlatmak, fakir ve hasta olan çocuklara tedavi imkânı sunmak ve çocukları sigara ve içkiden korumak gibi kurallar koymuştur (Okay, 1999, s. 16). Cemiyet ahlaki olarak da bazı kurallar koymuştur. Örneğin, çocukların iyi bir ahlaka sahip olmasının gerekliliğini savunmuştur. Bundan dolayı çocukların ticari bir meta haline getirilmesinin yasak olmasını ve çocukları ahlaki yönden yıpratacak fuhuş, meyhaneler, zararlı içeriğe sahip tiyatro ve sinemalardan da uzak durmaları gerektiğini açıklamıştır. Çocuk ahlaksızlığa ebeveyn tarafından düşürülmüşse cemiyet çocuğu kanun ile anne ve babasından ayırarak salim bir kişiye nakletmeyi amaç edinmiştir. Özürlü çocukların bakımını sağlamak, kız çocukları için parasız ev imkânı sunmak, zorunlu eğitim kanununun uygulanmasını sağlamak ve çalışan kadınlara gündüz bakımevi inşa etmek de cemiyetin politikaları arasında yer almıştır (Okay, 1999, s. 17). 
Cemiyetin hizmet politikalarının çeşitliliğinden bahsetmeden önce bu politikaların maddiyatla alakalı olduğunu ve hizmet çeşitliliğinin bu doğrultuda şekillendiğini de unutmamak gerekmektedir. Çünkü bahsedilen bu faaliyetlerin çeşitliliği maddi imkânlara dayanmaktadır. Bu sebeple kurum çocukların öncelikli gereksinimleri doğrultusunda hareket etmiştir. Böylece Süt Damlalarını kurmuştur. Bu birimin kuruluş amacı çocuklara sağlıklı ve temiz süt dağıtarak sağlıklı bir nesil yetiştirmektir. Böylece kurum, açlığın ve çocuk ölümlerinin de önüne geçmek istemiştir (Acar, 2011, s. 25). Çocuklar için tüketilen et ve süt ihtiyacının karşılanması için kuruma ait olan bahçede inek beslenilmiştir (Acar, 2011, s. 30). Kurum okul çağında olan çocuklara gıda hizmeti sunmak için aşevleri açmıştır. Aşevleri iki farklı hizmet vermektedir. Bu hizmetlerden biri Talebe Sofraları diğeri de Aşevleridir. Talebe Sofraları, öğrenciler için bol kalorili ve temiz yiyecekler yedirmek amacıyla kurulmuştur. 1927 yllına gelindiğinde ise kurum çocuklar için banyolar açmıştır (Acar, 2011, s. 26). Ayrıca cemiyet broşür, poster ve dergiler aracılığıyla birçok konuyla ilgili vatandaşları bilgilendirerek ebeveynleri eğitmiştir. Yine bu bağlamda cemiyet tarafından çocuk ve çocuğun bakımı ile ilgili birçok telif ve tercüme eser yayınlanmıştır. Bunun yanı sıra 23 Nisan Çocuk Bayramı olarak kabul edilmesi ve çocuk haftasının bütün yurtta kutlanması bu konuda atılan önemli adımlardan birisi olmuştur. 23 Nisan sadece Çocuk Bayramı olarak kutlanmakla kalmamış çocukların sorunları halka duyurulmuş böylece cemiyet ve devlet çocuk konusunda yapılacak olan faaliyetlerini ve gayelerini halka anlatma girişiminde bulunmuşlardır (Sarıkaya, 2007, s. 326). Trakyada Yeşilyurt gazetesinde de 23 Nisan ile ilgili yer alan haberde, Kırklareli halkının bayram hazırlıklarına 22 Nisan sabahı başlayarak her yerin bayraklarla donatıldığı ve 23 Nisan'da Cumhuriyet meydanında toplanıldığı ifadelerine yer verilmiştir (23 Nisan Nasil Geçti?, 1943).

Kurum, çocukların sağlığı ve yaşamlarının devamı için çocuk yuvaları ve şefkat yurtları açmıştır. Bu yuvalardan şu şekilde bahsedilmiştir:

\begin{abstract}
Bu yuvalar; minicik beyaz karyolalarında, beyazlar giyinmiş şefkatli hemşirelerin seven ve anlayan bakımı altında cıvıldayan, parmaklarını emerek masum yüzleri insanı içlendiren bebekleriyle görenler, bir insan çiçeği bahçesinde imişçesine, bir derin ve tatlı, bir büyük ve kuvvetli güvenin dalga dalga ruhunu bürüdügüünü hisseder.
\end{abstract}

$\mathrm{Bu}$ yuvalarda boy boy ve renk renk bebekler, çocuk bakımından hiçbir şartını unutmayan titiz bir ihtimamla büyütülürler. Bunlar arasında, anasını kara toprağa vermiş, varlıklı babaların yavruları da vardır. Bunları görmek, insanın bütün ömrü boyunca seve seve ve zevkle, güvenle, hatırlayacağı çok derin izler bırakır (Bartu, 1946).

...Çocuk Yuvası ismini verdiğimiz bu müessesede, süt çağından itibaren alınarak eli ekmek tutuncaya kadar himaye edilmesi icap eden çocuklar bakılmaktadır. Alınan çocukların ekseriyetini köylerde süt çağında iken anası ölen ve öksüz kalan yavrular teşkil etmektedir (Türkiye Çocuk Esirgeme Kurumu, 1940, s. 26).

Aslında çocuk yuvalarındaki atmosferi ve çocuk yuvalarının genel durumunu tek cümleyle şu yazı özetlemiştir: "Bu müesseselerdeki bebekler; kanat alıştırıp uçuncaya kadar yuvada bekleyen yavru kuşlar gibi, okullara yerleştirilinceye kadar, ana, babaları tarafından alınıncaya kadar, bakılıp büyütülür, yetiştirilip geliştirilirler." (Bartu, 1946). Buradan da anlaşılacağı üzere Çocuk Esirgeme Kurumu, çocuklara gerçekten anne, baba şefkatini ve sevgisini yaşatmaya çalışmıştır.

Cemiyetin çocuklara sunduğu diğer bir hizmet, gündüz bakımevleri açma girişimidir. Burada anneleri çalışan çocuklar, annelerinin iş saati süresince kurumda çalışan bakıcılar tarafından bakılmışlardır. $\mathrm{Bu}$ durum kurum sayesinde sistemli bir şekilde yürütülmüştür ki ilerleyen süreçte gündüz bakımevlerinde çalışacak elemanların yetiştirilmesi için Çocuk Bakıcı Ortaokulu açılmıştır. Ankara'da açılan bu okulun amacı çocukların bakımını sağlayacak elemanlara en modern yöntemlerle çocukların bakımının 
öğretilmesi olmuştur. Bu okulu bitiren öğrenciler çocuk bakıcısı olarak mezun olmuşlardır (Bartu, 1946). Bu okuldan mezun olanlar sadece Çocuk Esirgeme Kurumunda değil farklı kurumlarda da çocuk bakıcısı olarak çalışabilmişlerdir (Acar, 2011, s. 34).

Cemiyetin çocuk koruma politikası sadece kimsesiz ve öksüz çocukları değil tüm çocukları kapsamaktadır. Bu doğrultuda bütün çocukların hayatını ve hukukunu korumak cemiyetin görevi olarak benimsenmiştir. Ayrıca kurum çalışmalarını çocukların doğumundan itibaren ele almakla kalmayarak doğum öncesi de çalışmalar yürütmüştür. Bu çalışmalarda evlenecek kişilerin beden ve ruh sağlıklarının eşit olması gerekliliğini, gebelik döneminde annenin yanında bulunması gereken sağlık kurallarından çocuğun; doğum, emzirilme, beslenme, ylkanma, muayene, bakım, oyun ve okul dışındaki okuma faaliyetleri en ince ayrıntısına kadar eksiksiz bir şekilde ele alınmıştır. Bununla birlikte çocuk ölümlerinin ve çocuk düşürmenin önüne geçmek de kurumun çalışmaları içinde yer almıştur (Bartu, 1946). Cemiyet ile ilgili en göze çarpan ve özet olarak söylenebilecek görüşş̧udur ki; "Cemiyetin maksadı çocukları himayedir ve cidden muhteremdir." (Okay, 1999, ss. 28-29).

1. Dünya Savaşı, tüm şiddetli haliyle sürerken savaşın olduğu bölgelerden getirilen kimsesiz çocuklar Harbiye Mektebine yerleştirilmiştir. Himaye-i Etfâl Cemiyeti, mektepte bulunan çocuklarla ilgili Harbiye Nezareti ile bir görüşme yapılarak yeterli ödenek sağlandıktan sonra mektepteki çocuklar, Himaye-i Etfâl Cemiyeti tarafından bakılmaya başlanmıştır (Çavuşoğlu, 2005, s. 12). Bu misafirhane ilk önce 100 yatak kapasitesine sahip olarak hizmet vermeye başlamıştır. Ancak cemiyetin amacı daha çok çocuğa hizmet vermektir. Cemiyetin misafirhanesindeki bu çocuklar yetiştirilmek üzere, bazı ailelere evlatlı, ticaretle uğraşanların yanlarına çırak ve bazı okullara ise talebe olarak verilmiştir. Böylece misafirhanede boş kalan yerler için yeniden çocuk alınmıştır (Okay, 1999, ss. 30-31).

Himaye-i Etfâl Cemiyetinin önem verdiği öncelikli konulardan biri sağlık konusu olmuştur. İstanbul'da bazı fakir semtlere muayene evi açarak anne ve çocuklar için para vermeden tedavi olabilmelerini kararlaştırmıştır. Ayrıca cemiyet, İstanbul'da üç tane dispanser açmıştır. Bu dispanserler Şehzadebaşı, Kadıköy ve Bakırköy'de açılmıştır. Sonraki süreçte Üsküdar'da bir dispanser daha açlmıştır (Okay, 1999, s. 35).

Milli Mücadele yllarında cemiyetin üyelerinden olan birçok kişi Ankara'ya geçmiştir. Çünkü İstanbul işgal altında olduğu için cemiyetin çalışmaları güçleşmiştir. Ayrıca Himaye-i Etfâl Cemiyetine yapılan maddi destek yavaş yavaş azalmaya başlamıştır. Tam da bu sıralarda Ankara'da yeni bir Himaye-i Etfâl Cemiyeti kurulmuştur (Acar, 2005, s. 12). TBMM’nden bazı üyelerin girişimleriyle İstanbul'da bulunan Himaye-i Etfâl Cemiyeti ile aynı adı taşıyan cemiyet, Ankara'da 23 Nisan 1920'de kurulmuştur. Cemiyet isim olarak benzerlik taşımakla birlikte nizamnameleri ve kurucuları açısından da benzerlik bulunmaktadır (Okay, 1999, s. 56).

Kurum, tekrar 30 Haziran 1921'de yapılandırılmıştır (Sarıkaya, 2010, s. 194). Fakat kurum tekrar kurulmasına rağmen Kurtuluş Savaşı nedeniyle çalışmalarına tam olarak başlayamamıştır. Çünkü Kurtuluş Savaşı'nda Osmanlı Devleti birden çok cephede savaşmak zorunda kalmıştır. Bu nedenle cephelerde savaşan kişilerin çoğu şehit düşünce kimsesiz çocuk problemi günden güne artmıştır. Bu sebeplerden dolayı kurum çalışmalarına ancak 1 Ekim 1921 yılında esas olarak başlamıştır (Çavuşoğlu, 2005, s. 4).

Cemiyete parasal yardım talebinde bulunmak amacıyla ilk olarak Mısır ve Hindistan ardından diğer Müslüman devletler ile bağlantı kurulmuş ve bu ülkede bulunan çocuklar için Türkçe, Arapça ve 
Farsça olmak üzere mektuplar yazılmıştır. 22 Ekim 1921 tarihinde Hindistan ve Mısır'a yollanan mektupların bir kesiti aşă̆ı da şu şekildedir:

\begin{abstract}
...Analarınızı, babalarınızı, Allah'ınızı, Peygamberinizi hoşnud etmek isterseniz, işte kardeşler, harçlığınızdan böyle öksüz hakkı ayırıp biriktiriniz ve biriktirdikçe peder ve validelerinize verip diyiniz ki Türkiye'deki gözleri yaşlı ve kalpleri yaralı Müslüman küçük kardeşlerimize verilmek üzere bu hediyelerimiz Himaye-i Etfal Cemiyeti'ne mahsustur (Okay, 1999, s. 51).
\end{abstract}

Böylece sadece ülke içindeki yardımlarla yetinilmeyip ülke dışından da yardım talebinde bulunmuştur. Bu ülkeler özellikle Müslüman ülkeler ya da içinde Müslüman gurbetçi olarak yaşayıp Türk nüfusunun yoğun olduğu ülkeler olmuştur.

Dönemin özelliklerine bakıldığında, köyler uzun süren savaşların neden olduğu ekonomik ve sosyal yıkımdan fazlasıyla etkilenmiştir. Bundan dolayı Dr. Fuad Umay, köylerin kültür ve gelir düzeylerini yükseltmek amacıyla vilayet merkezlerinde yardım heyetleri kurulması ile ilgili meclise bir kanun teklifi sunmuştur7. Savaşlar sonucunda azalan bir erkek nüfus ve dağılan aileler ortaya çıkmıştır. Nüfusun büyük çoğunluğunu nitelik olarak eğitimsiz kişiler oluşturmuştur. Ayrıca bu dönemde sağlık ve sosyal imkânlar da sınırlı kalmıştır. Basın organları da bu dönemle ilgili veriler sunmuştur. Buna göre döneme ait önemli sorunlar içerisinde yer alan konulardan birisi çocuk ölümleri olmuştur. Çocuk ölümleri, dönemin gazetelerinde de sık sık yer almıştır (Acar, 2005, s. 4).

Çocuk Esirgeme Kurumunun ilk 25 yllında yaptığ faaliyetler kısaca şu şekilde özetlenmiştir. 1922 yılında kurum çalışmalarını muayene ve tedavi, para yardımı ve koruma olmak üzere üç alanda yapmıştır. Bu zamana kadar muayene ve tedavi edilen çocuk sayısı 612.044, para yardımı yapılan çocuk sayısı 99.286 ve himaye edilen çocuk sayısı ise 11.474'tür. 1923 yllına gelindiğinde 517.117 çocuğa yiyecek yardımı yapılmıştır. 1924 yılında ise paralı ve parasız olmak üzere çocuklara süt dağıtımına başlanmıştır. Böylece 1.337.050 Türk çocuğuna pastörize olarak süt dağıtılmıştır. Çocuk Esirgeme Kurumu her geçen yıl çocuklar için yaptığı yardımları arttırmıştır. Böylece 1925 yılında diğer yıllarda yapılan yardımlara ek olarak yeni bir yardım çeşidi olan sair yardımlar olarak ek bir bölüm daha ilave edilmiştir. 30.757 çocuk bu yardımdan yararlanmıştır. 1926'da çocuklara yiyecek temini, doğum yardımı yapılmış ve okul ihtiyaçları dağıtılmıştır (Bartu, 1946). 1926 yılında Çocuk Esirgeme Kurumu, yüksek gelir elde ederek diğer şubelerine para yardımı yapmıştır. Bu yardım 370.806 liraya kadar çıkmıştır. 1927 yllına gelindiğinde kurum çocuklar için banyolar açmış ve bu banyolarda toplam 629.861 çocuk ylkanmıştır. 1928 yllında ise çocuk bahçeleri kurulmuştur. Bu çocuk bahçelerini 2.796.454 çocuk kullanmıştır. 1929 yılında kurumda çocuklara diş tedavisi yapılmaya başlanmış ve 158.825 çocuk bu tedavi imkânından yararlanmıştır. Bu anlamda kurum, yardım şekillerini 15 bölüme çıkarmıştır. Ayrıca 1940 yılında çocuk kütüphaneleri oluşturulmuş ve bu kütüphanelerden 241.427 çocuk yararlanmıştır. Kurum, sadece çocukları himaye etme amaçlı faaliyetler yapmamıştır. Çünkü 1942 yılında Çocuk Bakımı Öğütleri adlı kitabı yayımlayarak 33.618 anneye bu kitabı göndermiştir (Bartu, 1946). Böylece çocuk sahibi olan anneler çocuk bakımı konusunda güvenilir kaynaklardan bilgi edinerek bilinçli bir şekilde çocuk yetiştirmeye başlamışlardır.

Kuruma gelir getiren diğer noktalar ise kurban, zekât ve fitre gelirleridir. Kurban derisi, zekât ve fitre gelirleri 1926'da Türk Hava Kurumu ve Çocuk Esirgeme Kurumuna verilmiştir (Acar, 2005, s. 51). Ayrıca cemiyete gelir sağlamak amacıyla çeşitli bağış kampanyaları açılmıştır. Cemiyet tarafından yapılan çalışmalar üyelere, bağışçlara ve kamuoyuna gösterilmek amacıyla düzenli olarak hesap tutulmuştur. Balolar ve piyango çekilişleri kuruma gelir getiren faaliyetler içerisinde yer almaktadır.

Başbakanlık Cumhuriyet Arşivi (BCA), 30.10.o.o. Yer 4.21.10. Bkz. Ek 1

Kurklareli University, Faculty of Arts and Sciences, Department of

Turkish Language and Literature, Kayalı Campus-Kırklareli/TURKEY

e-mail: editor@rumelide.com 
Balolar çoğunlukla 23 Nisan haftasında düzenlenerek hem kurumu ve kurumun çalışmalarını tanıtıp hem de bu amaç doğrultusunda bilet satışı gerçekleştirmektedir. Böylece burada satılan biletler kuruma gelir getirmektedir. Piyango çekilişleri ile ise çekilişe katılan kişilere eşya dağıtımı yapılmaktadır (Acar, 2005, 50). Bu faaliyetlerden sağlanan gelirler büyük rakamlar değildir. Ancak özellikle balolara devlet adamlarının gelmesi Çocuk Esirgeme Kurumunun farklı sorunlarını onlarla paylaşma fırsatı sağlarken sorunlara çözüm bulma şansı da elde edilmiştir.

Ankara Hükümeti'nin ortak fikri olan İstanbul'da bulunan kuruluşların Milli Mücadeleye olumsuz bakmalarından dolayı Ankara Himaye-i Etfâl Cemiyeti İstanbul'da bulunan Himaye-i Etfâl Cemiyetini yok saymıştır. Ankara'da TBMM tarafından yürütülen Milli Mücadele başarı ile sonuçlanınca Ankara Himaye-i Etfâl Cemiyeti İstanbul'da bulunan cemiyete temsilci göndermiştir. Ancak bu temsilci zamanla bireysel olarak hareket etmeye başlamış ve Ankara Himaye-i Etfâl Cemiyeti adına neşriyatta bulunarak çeşitli yardımlar toplayıp İstanbul'da Ankara'daki cemiyete üye kaydetmeye başlamıştır. Bu olaylar sonucunda gerginleşen ortam ile birlikte İstanbul halkı her iki cemiyet arasındaki farkı anlamakta zorlanmıştır. İlerleyen süreçte İstanbul'daki cemiyetin bağışlarında azalma olmuştur ama cemiyet bu bağışlardan çoğunu Ankara'ya gönderme fikrine olumsuz bakmamıştır. Damat Ferid Paşa Hükümeti döneminde Himaye-i Eytam Cemiyeti kurulunca isim benzerliğinden dolayı Himaye-i Etfâl Cemiyetinin bağış toplaması daha da zorlaşmıştır. Ancak tüm zorluklara rağmen cemiyet faaliyetlerinden vazgeçmemiştir (Okay, 1999, ss. 57-59). İstanbul'da bulunan Himaye-i Etfâl Cemiyeti, Ankara Himaye-i Etfâl Cemiyeti ile birleşmek istemiştir ancak Ankara'daki cemiyetten bir sonuç çlkmamıştır. 26 Ekim 1922'de Refet Paşa Ankara'dan İstanbul'a gelerek cemiyeti ziyaret etmiştir. Bu ziyaret sonucunda Refet Paşa'ya, cemiyetlerin nizamnamelerinin hemen hemen aynı olduğunun ve ortak amaca sahip olunduğunun bu nedenle iki cemiyet arasında fark olmadığının bilgisi verilmiştir. Dr. Fuad Umay’a göre her iki kurumun birlikte çalışması gerekmektedir. Böylece çocuklara daha iyi hizmet sunulabilecek ayrıca yurtdışından gelen bağışlar tek bir merkezde toplanabilecektir. İstanbul'un hem hilafet merkezinde olması hem de Ankara'ya göre daha yoğun nüfusa sahip olması nedeniyle İstanbul Himaye-i Etfâl Cemiyeti mektup ile Ankara'ya cemiyetin önemini ve merkezi kabul edilmesi gerektiğini bildirmiş̧ir (Okay, 1999, ss. 60-61).

Cemiyet kuruluşundan 15 yll sonra çocuk konusuna daha kapsamlı bakarak çalışmalarını bu yönde geliştirmeye başlamıştır. Böylece çalışma birimine psiko-sosyal ve sağlık konularını da dâhil etmiştir. Ayrıca kurum, devletin nüfusu arttıran politikalar üretmesine de destek olmuştur (Acar, 2005, s. 19). Himaye-i Etfâl Cemiyetinin adı 1935’te Türkiye Çocuk Esirgeme Kurumu olarak değiştirilmiştir. 1937 yllına gelindiğinde ise Bakanlar Kurulunun kararı ile kamu yararma çalsşan dernek statüsüne geçmiştir (Çengelci, 1998, s. 21).

Sonuç olarak 1921 ve 1939 tarihi aralığında kurum hızlı bir şekilde büyüyerek finansal olarak da önemli bir başarıya ulaşılmıştır. Ulaşılan bu başarı sonucunda hizmet çeşitliliği de artış göstermiştir (Acar, 2005, s. 56). Zamanla sayısı artan sivil toplum örgütleri, Çocuk Esirgeme Kurumunun konumunu kısmen de olsa zedelemiştir. Diğer taraftan Türkiye ekonomisinin kötü durumda olması ve halkın da yllarca süren yoksulluğu nedeniyle kuruma yapılan bağışlarda azalmıştır. Böylece Çocuk Esirgeme Kurumu sahip olduğu itibarlı konumunu yitirmekle karşı karşıya kalmıştır. Çünkü kuruluşunu Atatürk'ün başlattığı bu kurum, Atatürk'ün ölümüyle birlikte hem devletten hem de dönemin devlet adamlarından yeterli desteği görememiştir (Acar, 2005, ss. 43-44).

Himaye-i Etfâl Cemiyeti, çocuk davasını ve cemiyeti ele alan konularda uluslararası düzeyde birçok kongre, sergi ve toplantılara katılmıştır. Bunlardan başlıcaları aşağıdadır: 
- New York Himaye-i Etfâl Kongresi- 8 Nisan 1923

- Etfâle Muavenet Beynelmilel İttihadi 6-8 Ekim 1924 Senesinde Viyana ve Budapeşte'de İnikad Eden Çocuk Kongresi

- Amerika'da Açılacak İçtimai Sıhhi Çocuk Kongresi - Mayıs 1925

- Cemiyeti Akvam Kadın Ticareti ve Himaye-i Etfâl İstişari Komisyonu Beynelmilel Mesai İdarehanesinden Muhacirlerle İlgili Rapor - Haziran 1925

- Fransa'da Himaye-i Etfâl Kongresi - (2-5 Haziran 1927)

- Beynelmilel Himaye-i Etfâl İttihadının 8. İçtimai Umumisinin Raporu - 1927

- Brüksel Çocuk Sergisi 30 Haziran 1928 ve 21 Eylül 1928

- Pedagoji Teşekkülleri Cihan Federasyonu Kongresi (27 Temmuz-4 Ağustos 1929)

- $\quad$ Danimarka'da Beynelmilel Çocuk Kongresi - Eylül 1929

- Amerika'da Toplanan Çocuk Himaye ve Yardım Konferansı - 1931

- Paris’te Toplanan Milletler Arası Çocuk Himayesi Kongresi (13 Haziran 1933)

- Atina'da Toplanan Balkan Çocuk Esirgeme Kongresi - Mart 1936 (Sarıkaya, 2007, 274-275).

Himaye-i Etfal Cemiyeti'nin tüm amacı, hem himayeye muhtaç tüm çocukları korumak hem de tüm çocukların en iyi şartlarda, ilim ve tekniğin tüm sınırlarının zorlanmasıyla çocukların en iyi şekilde yetişmelerini sağlamak olmuştur. Kısacası Himaye-i Etfal Cemiyeti için çocuk demek milletin istikbali demektir (Sarıkaya, 2003, s. 201).

Himaye-i Etfâl, “çocuk koruma/esirgeme" anlamına gelmektedir. Kavram, Arapça "tıfil” kelimesinin çoğulundan üretilen "çocuklar" ve koruma, gözetme, esirgeme anlamına gelen "himaye" sözcüklerinin birleştirilmesi ile oluşturulmuştur. ${ }^{8}$

Himaye-i Etfâl Cemiyetinin ne zaman ve nasıl kurulduğuna, bunların ne süreli ve ne tür faaliyetler gerçekleştirdiğine ilişkin araştırmacılar arasında fikir birliği olduğunu söylemek güçtür. Kimi kaynaklarda Balkan Harbi döneminde ailelerini kaybeden çocuklara sosyal bir koruma sağlamak maksadıyla kurulduğuna ilişkin görüşler yer almakta, kiminde Osmanlı Dönemi’nde İstanbul merkezli Himaye-i Etfâl Cemiyetinin kuruluşuna ve Anadolu'da teşkilatlanmasına dair belgeler sunulmuştur. Cumhuriyet dönemi kaynaklarında ise 1921'de Ankara'da kurulan Himaye-i Etfâl Cemiyetine vurgu yapan Şahin ve Albayrak yazdıkları makalelerde, Himaye-i Etfâl Cemiyetinin yerel düzeyde ilk kez Kırklareli'de, genel ve ulusal düzeyde ise İstanbul'da kurulduğunu ifade etmiştir. Ayrıca TBMM'nin açılmasının ve yeni Türk Devletinin kurulmasının ardından da 30 Haziran 1921 tarihinde Ankara'da ihyaen kurulduğunu belirtmiştir (Albayrak, 1988, ss. 31-33). Akın'a göre İstanbul merkezli Himaye-i Etfâl Cemiyetinin Kırklareli'de şubesinin açlış tarihi 1922 olarak ifade edilmiştir. Okay’a göre ise İstanbul merkezli Himaye-i Etfâl Cemiyetinin Kırklareli şubesi 20 Eylül 1917 tarihinde açılmıştır.

8 Himaye: koruma, gözetme, esirgeme; Tifil: çocuk, (TDK, 2009). 
Dr. Fuad Umay'ın Kırklareli'de Himaye-i Etfâl Cemiyetinin kuruluş çalışmalarına sağladığı katkıya ilişkin kritik bilgiye Dursunkaya'nın Krrklareli Vilayetini Tarih, Coğrafya, Kültür ve Eski Eserleri Yönünden Tetkik adlı eserinde ilin eski valilerinden Kemal Gedeleç ile olan hizmetlerinden bahsettiği bölümde yer verilmektedir. 1916-1917 yllarında Kırklareli’nde görev yapan Kemal Bey’in yaptı̆̆1 hizmetleri sayarken “... Kirklareli"nin en havadar mevkiinde bir Darüleytam tesisine karar verilerek istimlak muamelesini yapmış ve 4 Haziran 1333'te inşaatı başlatmıştır” ve “...inşaat komisyonunda büyük emek ve hizmeti geçmiş olan Dr. Fuat Umay’ ebedileştirecek bir eser...” (Dursunkaya, 1948, s. 154) ifadelerine yer vermiştir. Anlaşlacağı üzere, Dr. Fuad Umay’ın Kırklareli’nde, Dursunkaya'nın Darüleytam olarak ifade ettiği fakat esasında Himaye-i Etfâl Cemiyetinin bir şubesi olarak faaliyet gösterecek olan fiziki altyapının kurulması için 1917 yılında gerekli çalışmaların içinde aktif olarak yer aldığı anlaşılmaktadır. Yine Dursunkaya'nın ifade ettiği gibi "Kırklareli bu eserle her vakit övünebilir." denilebilir (Dursunkaya, 1948, s. 154).

Dr. Fuad Umay için Himaye-i Etfâl Cemiyeti bir dönüm noktası olmuştur. Çünkü bir ömür boyu sürecek “Çocuk Davası”nın9 ilk kurumsal çatısı belirlenmiştir. Osmanlı'nın son bulması, TBMM’nin açlması sonrasında yeni devlete geçiş sürecinde, Dr. Fuad Umay öncülüğünde Türkiye Himaye-i Etfâl Cemiyeti 30 Haziran 1921 tarihinde Ankara'da tekrar kurulmuş ve amacı aşağıdaki şekilde belirtilmiştir:

I. Dünya Savaşı ve onu izleyen bir sürü çetin ve acılarla dolu savaşların, ülkemizde doğurduğu yıkımlardan olmak üzere, şehit çocukları ile bakım ve korunması millete kalan diğer sıkıntılara ve felaketlere uğramış çocukların, milletçe korunması ve yedirilip içirilmesi ve öteki felaket görmüş çocuklar ve bütün memleket çocuklarının hayatlarının korunması, maneviyatlarının güçlendirilmesi, her birinin hayatla savaşmaya yatkın ve ülkeye faydası olabilecek düzeyde eğitilmesinin sağlanması, araştırılması ve hazırlanması ve geleceğimizin temeli olan, bu günkü ülke çocuklarının bütün şefkatli bir gözle gözetilmesi ve bunun gerçekleştirilmesi... (Sarıkaya, 2007, s. 322 ).

İlk şubesini Kurklareli'de açttğı Himaye-i Etfâl Cemiyetinden sonra, Ankara Merkezli Himaye-i Etfâl Cemiyetini kuran Dr. Fuad Umay ise, bu cemiyetin başkanlığını 1950 yllına kadar sürdürmüştür. Dr. Fuad Umay, öncelikle kurmuş olduğu bu cemiyet aracılığıyla çocuklara yönelik çok kıymetli katkılar sağlamış, Cumhuriyet nesillerinin yetişmesinde öncü rol oynamıştır.

Dr. Fuad Umay, Amerika'da bulunan Türk Teavün Cemiyetinin davetiyle (Sertel, 2015, s. 62) 25 Mart 1923 yılında Amerika'ya gitmiştir. Dr. Fuad Umay, ülkenin çocuk sorununa kalıcı bir çözüm getirmek amacıyla ilk olarak Himaye-i Etfâl Cemiyetini kurarak, cemiyetin öncülüğünü burada yapmaya başlamıştır. Akabinde milletvekili olarak mecliste söz hakkına sahip olduğu için meclise; çocukların yaşamı, refahı ve huzuru için kanun teklifleri sunarak savaş döneminden çıkan halkın sözcüsü durumunda olmuştur. Meclise sunduğu ilk teklif, Himaye-i Etfâl Cemiyetinin kamu yararına çalışması ve halkın yardımları sonucu cemiyetin ayakta durması sebebiyle bu kurumun bazı masraflarının devlet tarafından ücretsiz olarak karşılanması ile ilgilidir. Böylece Dr. Fuad Bey 16 Ocak 1922'de (Hilal-i Ahmer Cemiyeti) Kızılayın posta ücretlerinden muaf tutulduğunu ve Himaye-i Etfâl Cemiyetinin de bu ücretlerden muaf tutulması gerektiği istemiyle ilgili bir teklif sunmuştur. Dr. Fuad Umay, meclise üst üste sunduğu ve kabul edilmeyen kanun teklifini meclise onaylatmayı zor olsa da başarabilmiştir. Böylece 26 Kasım 1923 yılında çıarılan Posta Kanunu ile Himaye-i Etfâl Cemiyeti, dönemin posta ücretlerinden muaf tutulmuştur (Akın, 2001, s. 55). Sonuç olarak, Türkiye'nin en önemli iki hayır kurumu olan Himaye-i Etfâl Cemiyeti ve Hilal-i Ahmer Cemiyeti arasında posta ücretlerinin muafiyeti

9 “Çocuk Davası”, Türk Milletinin geleceğini teminat almak üzere iyi ve sağlıklı bireyler yetiştirmek ülküsü için Dr. Fuad UMAY'ın çabalarını ifade eden, kendi tanımlamasıdır. Bkz. Veysi Akın, Bir Devrin Cemiyet Adamı Dr. Fuad Umay. 
konusunda yapılan sözde ayrım ortadan kalkmıştır. Posta masraflarından elde edecekleri gelirler yardım amaçlı olarak kullanılmaya başlanmıştır. Zaten dönemi gerek siyasal gerek ekonomik gerekse sosyal durum açısından incelediğimizde, o yıllarda yetim çocukların bu tür yardımlara fazlasıyla ihtiyaçlarının olduğu bir gerçektir.

Dr. Fuad Umay tarafindan Ankara'da boş bir arsanın Himaye-i Etfâl Cemiyeti için hibe edilmesi konusunda Meclise bir teklif daha verilmiştir. Türkiye'de lunapark açma ve işletme hakkı belediyelerde bulunuyor ve belediyeler bundan büyük gelir elde ediyorlardı. Bu gelirin büyüklügünnden dolayı Dr. Fuad Umay lunapark tesislerini işletme imtiyazının Himaye-i Etfâl Cemiyetine verilmesi konusunda meclise teklif sunmuştur. Fakat bu teklif onaylanmamıştır. Daha sonra ise Dr. Fuad Umay, Himaye-i Etfâl Cemiyetine maddi bir getiri sağlayacak farklı bir öneri ile meclise teklifte bulunma kararı almıştır. Böylece para ile çalışan otomatik makinaların (tartı makinaları, sakız, şeker vb. maddelerin satış işlemini yapan makinalar) imtiyazının Himaye-i Etfâl Cemiyetine verilmesi konusundaki teklifini meclise sunmuş̧ur ${ }^{10}$. Böylece 1 Nisan 1930'da Resmi Gazete'de yayınlanarak on beş yll süreyle bu makinaların imtiyazı Himaye-i Etfâl Cemiyetine verilmiştir (Akın, 2001, s. 57). Ayrıca Dr. Fuad Umay aracılı̆̆ıyla 23 Nisan'ın çocuk bayramı olarak ilan edilmesinden dolayı çeşitli kurumların desteği alınarak çocuklar için özellikle kimsesiz çocuklar için programlar düzenlenmiştir. Fakat bu programlar sonucunda gerekli maddi destek elde edilememiştir. Bundan dolayı Dr. Fuad Umay, Çocuk Bayramı sebebiyle Şefkat Pulu kullanılması ile ilgili meclise bir teklif sunmuştur. Böylece 11 Nisan 1932'den itibaren her yıl 20-30 Nisan tarihleri arasında çıkan mektup ve telgraflara Şefkat Pulu yapıştırılarak geliri Himaye-i Etfâl Cemiyetine aktarılmıştır. Çocuk vergisi ile ilgili kanun teklifi ise meclise sunulup kabul edilmeyen kanun teklifleri arasında yer almaktadır (Akın, 2001, ss. 58-59).

Dr. Fuad Umay bazı film ve tiyatroların çocukları ruhsal yönden olumsuz etkilediğini düşündüğü için 8 Mart 1928'de çocukların umumi filmler ve tiyatrolara girişlerinin yasaklanması ile ilgili meclise teklif sunmuştur. Meclise sunulan bu teklif defalarca çeşitli sebeplerden dolayı reddedilmiştir. Dr. Fuad Umay'ın diğer bir kanun teklifi, çocukların içki ve tütün kullanmalarının yasaklanması konusundadır.

Sağlık alanında ise 1924 yllında meclise sitma ile mücadele konusunda bir teklif sunmuştur. Bu teklif kabul edilerek, Dr. Fuad Umay dönemin önemli hastalığı olan sitma ile mücadelede halka öncülük etmiştir. Çocuk Esirgeme Kurumunun dönemin şartlarına göre mükemmel bir yapı olduğundan aşağıda şu şekilde bahsedilmiştir:

\begin{abstract}
Rakamların âciz ifadeleri yanında bir büyük aşkın, akın akın ruhlara dolandığını, alev alev gönüllerde yandığını gösteren bu âbideler; TÜRKIYY BÜYÜK MİLLET MECLİSI'nin ruhundan kopan kanunlar, Türk aydınına ve Türk çocuğuna sunulan yayınlar, taşın ve betonun bilgi ve teknikle yoğrulmasıyla kurulan yapılardır (Bartu, 1946).
\end{abstract}

23 Nisan 1920'de TBMM kurulmuş böylece her Türk vatandaşı tam egemenlik hakkına sahip olmuştur. Çocuk Esirgeme Kurumunun en büyük faaliyetlerinden birisi 23 Nisan 1920 gününü Türk çocuklarına çocuk bayramı olarak armağan edilmesidir. Çocuk Esirgeme Kurumu telif ve tercümelerden oluşan anne ve babaları ilgilendiren çocuk konulu birçok eser sunmuştur. Ayrıca kurum Çocuk ve Türk Kadın dergilerini çıkartmıştır. Bu dönemde basımı yapılan dergiler sadece burada ismi geçen dergiler değildir. Çocuk edebiyatı ile ilgili bir komisyon kurularak bu komisyonun denetiminden geçen birçok çocuk kitabının da yayımı yapılmıştır (Bartu, 1946). 
İşte tüm bunlar göz önüne alınarak ortaya çıkan tabloya göre çocuk sorununun büyüklüğünden dolayı kurum için önemli olan faaliyetlerin ilki bağış toplamaktır. Çünkü toplanan bu bağışlar sonucu kurum daha fazla çocuğa ulaşmış ve büyümüştür. Bu nedenle kurumun halkın desteğine ihtiyacı vardır. Mustafa Kemal, çocuk sorununun öneminin farkındadır. Bu farkındalık Mustafa Kemal'in şu sözlerinden de anlaşılmaktadır: "Memleket çocuklarını korumayı üzerine alan Çocuk Esirgeme Kurumuna vatandaş yardıma mecburdur.” Kurumun başkanı olan Dr. Fuad Umay'ın ise bu konudaki sözleri şudur:

\begin{abstract}
Halkımız, halk egemenliğinin güçlü bir biçimde kurulabilmesi için önce çocukların egemenliğinin kurulmasının gerekli olduğunu benimsemeli ve bunu çocuklara önem vermekle göstermelidir. Çocuklara önem vermek çocukların varlık ve mutluluklarını sağlamayı görev bilen Himaye-i Etfâl Cemiyeti'ne yardım etmekle kendini gösterir. Bu yardımın düzenli bir şekilde, büyük kısmının halk tarafindan karşılanacağı gün, Türk çocuklarının tarihinde mutlu ve onurlu bir gün olacaktır (Acar, 2011, ss. 38-39).
\end{abstract}

Himaye-i Etfâl Cemiyeti, kısa süre içerisinde örgütlenerek hızla büyümüştür. Himaye-i Etfâl Cemiyetinin bu kadar kısa sürede büyümesinin en önemli nedeni artan şubelerin özellikle nahiye ve köy gibi en ücra yerlere bile ulaşabilmiş olmasıdır. Bu hızlı büyümede Meclisin ve Mustafa Kemal'in de büyük destekleri olmuştur (Acar, 2011, s. 15). Ayrıca cemiyetin çoğu yönetici ve üyesi milletvekili veya bürokrat olduğu için Meclis cemiyete kolaylıkla gelir sağlayabilmiştir (Acar, 2011, s. 41). Bu noktada meclis ile cemiyetin yakınlaşması kuruma maddi olarak gelir getirmesi açısından da önemlidir. Görüldüğü gibi cemiyet, savaş yıllarından sonra da kimsesiz çocuklara sahip çıkarak onların koruyuculuğunu yapmış ve çocukların hayata hazırlanması için ülkenin içinde bulunduğu zor şartlarda bile başarılı çalışmalarda bulunabilmiştir (Sarıkaya, 2003, s. 194).

Himaye-i Etfâl Cemiyetinin adı 1935’te "Türkiye Çocuk Esirgeme Kurumu" olmuştur. Böylece kapatılana kadar aynı isimle varlı̆̆ını devam ettirmiştir (Sarıkaya, 2005, s. 52).

Dr. Fuad Umay sadece Himaye-i Etfâl Cemiyetinin bünyesinde barındırdı̆̆ı çocuklar için değil cemiyetle ilgisi olmayan diğer çocuklar için de çeşitli teklifler sunmuştur. Bunlar içerisine en önemlisi olarak nitelendirebilecek olan önerge İdil Biret ile ilgili olan önergedir. Bu önerge İdil Biret’in henüz 5 yaşında bir çocuk iken etrafındaki güvenilir kişiler tarafından musikide kabiliyetli olduğunun duyumunu almış ve ileride ülkemiz için çok kıymetli sanatçılar arasında yer alabileceğini düşünerek Milli Eğitim Bakanı'na İdil Biret'in Amerika'da eğitim almasını sağlamak için yazılı bir önerge sunmuştur. Çünkü Dr. Fuad Umay'a göre, Amerika'da kişiye özel yetiştirme imkânı sunan kurumlar bulunmaktadır. Ayrıca İdil Biret'in ailesinin maddi durumu ne olursa olsun tam anlamıyla eğitim giderlerini karşlamaları olanaksızdır. Bu sebeple Dr. Fuad Umay, Milli Eğitim Bakanı'ndan İdil Biret’in Amerika'ya gönderilerek kişiye özel yetiştirme imanı sunan bir kurumda eğitim almasını ve bu eğitim giderlerinin karşılanması hakkında bir talepte bulunmuştur ${ }^{11}$

1921 ve 1939 tarihi aralı̆̆ında kurum hem çocuklara sunduğu sosyal hizmetleriyle hem de kendi bünyesinde maddi olarak hızlı bir şekilde büyüme göstermiştir. Fakat kuruma ait genel kongrelerdeki verilere bakıldığında özellikle Atatürk'ün ölümünden sonraki süreçte kurumun, maddi olarak kendi kendine yetemediği görülmektedir. Zamanla artan sivil toplum örgütleri ve Türkiye ekonomisinin kötü gidişatı Çocuk Esirgeme Kurumunu sahip olduğu saygın ve itibarlı konumunu yitirmekle karşı karşıya kalmıştır (Acar, 2011, ss. 43-44). Musikide olağanüstü kabiliyet gösteren İdil Biret hakkında Kırklareli Milletvekili Dr. Fuad Umay tarafından Milli Eğitim
Bakanlığı'na gönderilen sözlü soru önergesi, Ek 2'de sunulmuştur. 
Atatürk'ün ölümüyle birlikte kurum sıradan bir sivil toplum örgütüne dönüştürülmeye çalışllmıştır. Genel olarak 1950'lerden sonraki süreçte devlet sosyal hizmet alanında yapılan tüm çalışmaları kontrol altına alarak etkinliğini arttırmak istemiştir. İkinci Dünya Savaşı'nın getirdiği olumsuzluklar ve maddi olumsuzlukların da etkisi ile kurum saygınlığını kaybetmeye başlamıştır. Ayrıca devamındaki süreçte de 27 Mayıs 1960'ta gerçekleşen askeri darbe ile birlikte sosyal devlet anlayışının benimsenmesi, kurumu zayıflatan etkenler arasında gösterilmiştir (Acar, 2011, ss. 60-61).

Sonuç olarak baktığımızda Dr. Fuad Umay’ı sadece Himaye-i Etfâl Cemiyeti ile bağdaştırmanın da bir yanılgı olacağını belirtmek gerekmektedir. Çünkü yaşadığı süre boyunca Dr. Fuad Umay cemiyetçi kimliğinden bağımsız olarak birçok alanda Türk milletine hizmet etmiştir. Yine de Dr. Fuad Umay'ın kurduğu ulusal cemiyetleri ve şubeler ile mahalli cemiyetleri sıralamak gerekmektedir. Dr. Fuad Umay'ın kurduğu ulusal cemiyetler şu şekilde özetlenmiştir:

- Himaye-i Etfâl Cemiyeti (Çocuk Esirgeme Kurumu),

- Himaye-i Etfâl Kadın Yardım Cemiyeti (Yardım Sevenler Cemiyeti)

- Milli İktisad ve Tasarruf Cemiyeti (Ulusal Ekonomi ve Artırma Kurumu)

- Arı ve Kümes Hayvanları Yetiştirme Cemiyeti

- Dr. Fuad Umay'ın kurduğu şubeler ve mahalli cemiyetler de aşağıda özetlenmiştir:

- Müdafaa-i Milliye Cemiyeti Kırkkilise (Kırklareli) Şubesi

- Himaye-i Etfâl Cemiyeti Kırkkilise (Kırklareli) Şubesi

- Bolu Mûsiki Cemiyeti (Akın, 2000, ss. 108-119)

\section{Sonuç}

Dr. Fuad Umay, Kırklareli'nin yetiştirdiği bir doktor, bir milletvekili aynı zamanda bir cemiyet adamıdır. Bu nedenle Türk tarihinde hem siyasetçi kimliği ile hem de cemiyetçi kimliğiyle ön plana çıkmış ve Türk Tarihi'ne büyük katkıları olmuştur. Onun doktor olması çocuk sorununa karşı kalıcı çözümler üretmesine olanak sağlamıştır. Çünkü Osmanlı Devleti’nin geçirdiği art arda gelen savaşların sonucu olarak genç vatan evlatlarının arkasında bıraktığı kimsesiz, yardıma muhtaç çocuk sorununun çözümü için yapılan çalışmaların fikir adamı Dr. Fuad Umay’dır. Çocuklara olan koruyuculuğundan dolayı onun soyadı Mustafa Kemal Atatürk tarafından Umay olarak seçilmiştir.

O, çocuklar için Himaye-i Etfâl Cemiyetini kurarken aldığı tıp eğitimiyle yetinmeyerek Amerika'ya gitmiştir. Orada hem hali vakti yerinde olan Müslüman Türklerden maddi destek istemiş hem de Amerika'da yardıma muhtaç çocuklar için kurulan kurumları yakından inceleme imkânı bulmuştur. Bu konuda edindiği tüm izlenimlerini ve bilgilerini Himaye-i Etfal Cemiyeti için kullanmıştır. Cemiyet, 1935 yılında Türkiye Çocuk Esirgeme Kurumu adını alarak bu isimle anılmaya başlanmıştır.

Dr. Fuad Umay, sadece Himaye-i Etfâl Cemiyetine kaydı olan çocukları değil Himaye-i Etfâl Cemiyetine kaydı olmayan çocukları da himaye etmiş̧ir. Örneğin, Musikide Olağanüstü Kabiliyet Gösteren İdil Biret Adındaki Bir Çocuğun İstikbali Hakkında Milli Eğitim Bakanlı̆̆ı’na Gönderilen 
Sözlü Soru Önergesi, Dr. Fuad Umay'ın Himaye-i Etfâl Cemiyetine kaydı olmayan çocukları da himaye ettiğinin bir göstergesidir. Bu önergenin kabulü sonucunda İdil Biret Amerika'ya gönderilerek kişiye özel yetiştirme imkanı sunan bir kurumda eğitim almış ve eğitim giderleri Milli Eğitim Bakanlığı tarafından karşılanmıştır.

Dr. Fuad Umay, Tırnova'da doktorluk yaptığı dönem, Frengi Hastalığının halk arasında yayılmasını önlemek için sağlık muayenesi olmadan genç kızların evlenmelerinin mümkün olmayacağını dile getirmiştir. Bu sebeple Türkiye Cumhuriyeti’nde kıyllan nikâhlardan evvel çiftlerin sağllk muayenesinden geçmesi, Dr. Fuad Umay'ın Tırnova'da yaşamış olduğu tecrübe ve çabalarının bir sonucu olarak karşımıza çıkmıştır. Böylece Dr. Fuad Umay'ın kazanmış olduğu başarılar günümüze kadar varlığını devam ettirebilmiştir. Ayrıca dönemin önemli hastalı̆̆ı olan Sitma ile mücadele konusunda meclise teklif sunarak halka öncülük etmiştir.

Himaye-i Etfâl Cemiyetine Mustafa Kemal Atatürk’ün de büyük destekleri olmuştur. Ancak Mustafa Kemal Atatürk'ün vefatından sonra cemiyete maddi destek sağlanamamıştır. Bundan dolayı Türkiye Çocuk Esirgeme Kurumu kurulduğu yllara oranla pek gelişme gösterememişse de daha sonraki yıllarda çocuklar adına başarılı faaliyetler sürdürmüştür.

\section{Kaynakça}

\section{Arşiv belgeleri}

Başbakanlık Cumhuriyet Arşivi. Başbakanlık Muamelat Müdürlüğü 30.18.1.2 Yer No:17.10.2.

Başbakanlık Cumhuriyet Arşivi. Başvekâlet Yazı İşleri Müdürlüğü 30.10.o.o Yer No:4.21.10.

Başbakanlık Cumhuriyet Arşivi. Genel Kâtip Kanunlar Müdürlüğ̈̈ 30.1.o.o Yer No:53·318.3.

\section{Kitaplar ve makaleler}

Acar, H. (2011). Cumhuriyet'in Çocuk Refahı Politikasını Yapılandiran Bir Sivil Toplum Örgütü: Türkiye Çocuk Esirgeme Kurumu (1921-1981). Ankara: Fişek Enstitüsü Çalışan Çocuklar Bilim ve Eylem Merkezi Vakfi.

Akın, V. (2000). Bir Devrin Cemiyet Adamı Dr. Fuad Umay. Ankara: Atatürk Araştırma Merkezi.

Albayrak, H. (1988). Himaye-i Etfal Cemiyeti. Tarih ve Toplum, (52), 31-33.

Araz, Y. (2013). Osmanlı Toplumunda Çocuk Olmak. İstanbul: Kitap.

Arslan, Y. E. (2007). İslam Hukukunda Kimsesiz Çocuklar, Yayınlanmamış Yüksek Lisans Tezi. Cumhuriyet Üniversitesi, Sosyal Bilimler Enstitüsü, Sivas.

Bartu, V. (1946). 25 Yll (1921-1946), Ankara: Türkiye Çocuk Esirgeme Kurumu.

Bulut, F. (2009). Osmanlı'dan Cumhuriyet'e Tehlikeli Bir Miras: Frengi, Tarih Okulu, (3), 109-123.

Çağlar, D. (1973). Türkiye'de Korunmaya Muhtaç Çocuklar ve Eğitimlerine Genel Bir Bakış, Ankara Üniversitesi Eğitim Bilimleri Dergisi, 6 (1), 59-111.

Çağlar, G. (1990). Hüsrev Bey Heyet-i Nasihası (Nisan-Haziran 1920), Yayınlanmamış Yüksek Lisans Tezi. Atatürk Üniversitesi, Sosyal Bilimler Enstitüsü, Erzurum.

Çavuşoğlu, T. (2005). Sosyal Hizmetlerin Yakın Tarihinden Sayfalar, Türkiye Çocuk Esirgeme Kurumu Yapraklart 1917-1983, Ankara: Sabev.

Çeker, O. (2015). İslam Hukukunda Çocuk. Konya: Tekin.

Çengelci, E. (1998). Sosyal Hizmetler ve Çocuk Esirgeme Kurumu. Ankara: Aydınlar Matbaa.

Dursunkaya, A.R. (1948). Krrklareli Vilayetini Tarih, Coğrafya ve Kültür Eserleri Yönünden Tetkik. Kırklareli: Yeşilyurt Basımevi. 
Evcin, E. (2011). Birinci Dünya Savaşı'ndan Türkiye Cumhuriyetïnin Kuruluşuna Kadar Bolu ve Çevresi ve İz Bırakanları, Yayınlanmamış Doktora Tezi. Ankara Üniversitesi, Sosyal Bilimler Enstitüsü, Ankara.

Genelkurmay Başkanlığı. (2005). Arşiv Belgeleriyle Ermeni Faaliyetleri (Cilt 6), Ankara: Genelkurmay ATASE ve Genelkurmay Denetleme Başkanlığı Yayınları.

Kapcı, H. Z. (2016). Osmanl'dan Cumhuriyet'e Yetim. İstanbul: Kriter.

Kılıç, F. (2011). Bolu Müdafaa-i Hukuk Cemiyeti Faaliyetleri, Abant İzzet Baysal Üniversitesi Eğitim Fakültesi Dergisi, 11 (1), 29-37.

Koçer, H. A. (1991). Türkiye'de Modern Eğitimin Doğuşu ve Gelişimi (1773-1923), İstanbul: Milli Eğitim.

Koçu, R. E. (1974). Dârülaceze (1895-1974), İstanbul: İnkılap ve Aka Basımevi.

Konukçu, E. (1978). Bolu Bölgesine Ait Milli Mücadele Kronolojisi, Atatürk Üniversitesi Dergisi, 1 (1), 23-34.

Martal, A. (2007). Belgelerle Osmanlı Dönemi’nde İzmir. İzmir: Yazıt Yayıncılık.

Okay, C. (1998). Osmanh Çocuk Hayatında Yenileşmeler 1850-19oo. İstanbul: Kırkambar.

Okay, C. (1999). Belgelerle Himaye-i Etfal Cemiyeti 1917-1923. İstanbul: Şule.

Okur, Y. (1996). Darüleytamlar, Yayınlanmamış Yüksek Lisans Tezi. OMÜ, Sosyal Bilimler Enstitüsü, Samsun.

Özbek, N. (1999). II. Abdülhamid ve Kimsesiz Sokak Çocukları: Darülhayr-ı Ali, Tarih ve Toplum, 138, 11-20

Özbek, N. (2002). Osmanl İmparatorluğu'nda Sosyal Devlet. İstanbul: İletişim.

Özkan, S. (2006). Türkiye'de Darüleytamların Gelişimi ve Niğde Darüleytamı, Selçuk Üniversitesi Türkiyat Araştırmaları Dergisi, 19, 211-229.

Sarıkaya, M. (2003). Savaş Yıllarında Himaye-i Etfal Cemiyeti'nin Çocuk Misafirhanesi, Atatürk Dergisi, 3 (3), 193-203.

Sarıkaya, M. (2007). Cumhuriyet'in İlk Ylllarında Bir Sosyal Hizmet Kurumu: Türkiye Himaye-i Etfal Cemiyeti, Türkiyat Araştırmaları Enstitüsü Dergisi, (34), 321-338.

Sarıkaya, M. (2011). Türkiye Himaye-i Etfal Cemiyeti 1921-1935. Ankara: Atatürk Araştırma Merkezi.

Sarıkaya, M. (2012). Türkiye'de Zirai Eğitime Bir Örnek: Kalender Ziraat Yurdu, Acta Turcica Çevrimiçi Tematik Türkoloji Dergisi, 4, 87-101.

Sarıkoyuncu, A. (1992). Milli Mücadele’de Zonguldak ve Havalisi. Ankara: Kültür Bakanlığı.

Sertel, S. (2015). Roman Gibi. İstanbul: Can.

Şimşir, B. N. (1992). İngiliz Belgelerinde Atatürk, C. I, Ankara: Türk Tarih Kurumu.

TDK (Türk Dil Kurumu). (2009). Büyük Türkçe Sözlük. Ankara: Türk Dil Kurumu.

Toprak, Z. (2017). Erken Cumhuriyet, Nüfus Sorunu ve Çocuk Ölümleri. Toplumsal Tarih, (281), 2231.

Türkiye Çocuk Esirgeme Kurumu. (1940). Türkiye Çocuk Esirgeme Kurumu'nun Küçük Bir Tarihçesi 1921-1939, İstanbul: Resimli Ay Matbaası.

Tütüncü, Z. (1996). Türkoğlu Gazetesine Göre İstiklal Savaşı’nın Değerlendirilmesi, Yayınlanmamış Yüksek Lisans Tezi. Ankara Üniversitesi, Türk İnkılap Tarihi Enstitüsü, Ankara.

Umay, F. (1950). Seçmenlerimle Başbaşa. Ankara: Yeni Matbaa

Umay, M. F. (2014). Cumhuriyetin Kuruluş Yillarında Bir Devrimci Doktorun Anılar Dr. Mehmet Fuat Umay (Çev. C. Kayra), İstanbul: Türkiye İş Bankası Kültür. 
Yıldırım, M. A. (2013). Dersaâdet Sanayi Mektebi (İstanbul Sanayi Mektebi) 1868-1926, İstanbul: Kitabevi.

Yılmaz, C. (1991). Milli Mücadele'de Dertli Gazetesi, Yayınlanmamış Yüksek Lisans Tezi. Gazi Üniversitesi, Sosyal Bilimler Enstitüsü, Ankara.

23 Nisan Nasıl Geçti?. (1943, 26 Nisan). Trakya'da Yeşilyurt Gazetesi, 1242.

EK 1: Musikide olağanüstü kabiliyet gösteren İdil Biret hakkında Kırklareli Milletvekili Dr. Fuad Umay tarafından Milli Eğitim Bakanlığına gönderilen sözlü soru önergesi

\title{
TÜRKIYE BÜYÜK MILLET MECLISI
}

\author{
GE NEL KÃ T I P \\ KANUNLAR MUDURLUGU \\ S U R E T $11 . x I .1947$ \\ Yüksek Baģkanlzŏga
}

11.I. IY46 tarihinde Yaksek makaminiza aundugram ga : (Ulus gazetesinde bix kac gindic yayın lenen yazilarda Idil B1ret ismind be yaglarinda bir ka gocürom musikide harika addedileck bir kabllijet göaterakte oldugu en calâhlyet11 klmaler tarafindal belirtilmektedir . Vatanimiz igin gok kiymetil bir varlik elmeak olan un yavrumen anafingn babasinin duru-

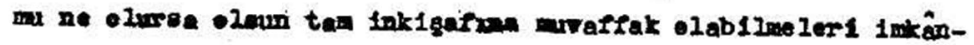
s1zâm .

Amerikada bu gibl ola ganta yaradiliglar igin hizeusi

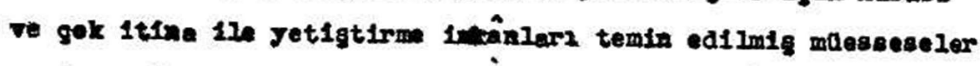

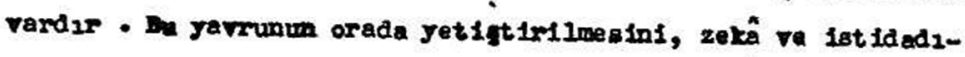

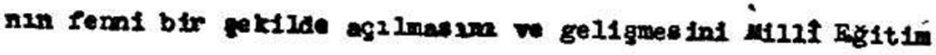
Bakanzmix temin edeblifrler mi 7 Vatanimax ig in maddî ve ment bir Hazine olacak olan bu ensalaia yavrunum Istikbail bakkanda

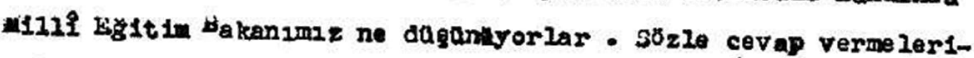
ni) onerg ile rica etmiģtim.

Bakanlıkga yapı Imzą -Im tetkikat onuma hakikaten

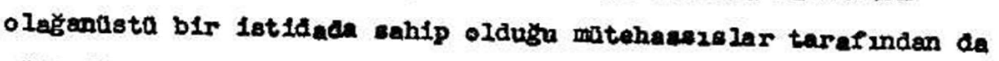
mutterikan 1 fade edilmf olan Id1l Blretin husues ve gok Itinal

\begin{tabular}{|l|l|l|l|l|l|l|l|}
\hline 030 & 01 & & & 5 & 1 & 1 \\
\hline
\end{tabular}




\title{
TÜRKIYYE BÜYÜK MILLLTT MECLİSİ
}

\author{
GENEL KÃTI P \\ KANUNLAR MUDURLUG U
}

S U R E T

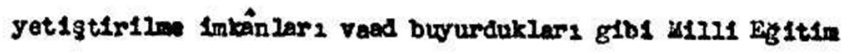

Bakanlyejenca aragt2urimigmadir vo netice ne olmugtur. Yurt

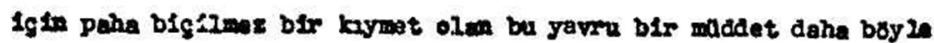

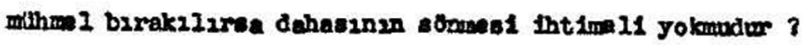

s̈zzle cevap verlimesinl rica odax, saygalamima sume-

sym.

Kuxklorel1 MLlletvek124

Dref. Unary

\section{Aslana workadu.}

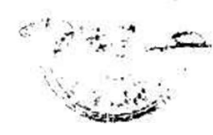

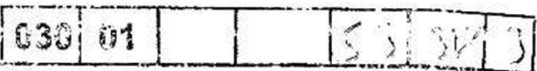


EK 2: Köylerin kültür ve gelir düzeylerinin yükseltilmesi için vilayet merkezlerinde yardım heyetleri kurulmasına dair, Dr. Fuad Umay'ın kanun teklifi 